\title{
Comparative study on lesions of reproductive disorders of cows and female dromedary camels slaughtered at Addis Ababa, Adama and Akaki abbatoirs with bacterial isolation and characterization
}

\author{
Aynalem Mandefro ( $\nabla$ anaafman@gmail.com ) \\ Hawassa University College of Natural and Computational Science \\ Tilaye Demissie Ayana \\ Addis Ababa University \\ Gemechu Chala Hunderra \\ Hawassa University \\ Tadesse Gidey Gebrezihar \\ Addis Ababa University \\ Bulto Giro Boru \\ Addis Ababa University \\ Natnael Teshager Desta \\ National Animal HealthDiagnostic and Investigation center, Sebeta, Ethiopia
}

\section{Research article}

Keywords: Cow, Dromedary camel, lesion, reproductive organ

Posted Date: December 18th, 2020

DOI: https://doi.org/10.21203/rs.3.rs-35515/v4

License: @) (i) This work is licensed under a Creative Commons Attribution 4.0 International License. Read Full License

Version of Record: A version of this preprint was published at BMC Veterinary Research on March 29th, 2021. See the published version at https://doi.org/10.1186/s12917-021-02822-z. 


\section{Abstract}

Background: Reproduction is a basic prerequisite to efficient livestock production. Reproductive performance depends upon the normal structure and function of genital organs.

Methods: A cross-sectional study was conducted from November 2016 to May 2017 to identify and compare the frequency of pathological lesions in the reproductive tract and to isolate bacteria associated to uterine lesions in female dromedary camels and cows slaughtered at Akaki camel slaughter house and Addis Ababa and Adama municipal abattoirs. Abattoirs were visited once per week for 28 weeks during which three to seven animals on average were slaughtered per day. A purposive sampling technique was employed to examine reproductive tracts of all slaughtered animals (280; 140 cows and 140 camels). Following gross inspection at abattoirs, tissue samples with lesion were collected for histopathological and bacteriological investigation.

Result: Various pathological lesions with different degrees of severity were observed in 48 (34.2\%) and 51 (36.4\%) of dromedary camels and cows, respectively. Uterine lesions were the most prevalent $21.4 \%$ lesions observed in dromedary camels followed by ovarian lesions 7.14\%; while in cows, ovarian lesions were the major prevalent $16.4 \%$ lesions followed by uterine lesion $14.2 \%$. The result showed that there were 56 bacteria isolated from cows uterine lesion with Staphylococcus species 28.5\%, Streptococci species 19.6\%, Coynebacterium species $8.9 \%$, Escherichia coli $26.78 \%$, Salmonella species $10.7 \%$ and Klebsiella species $5.35 \%$ being the prominent isolates; while in camels, there were 45 bacteria isolated with Escherichia coli $35.5 \%$, Staphylococcus species 26.6\%, Streptococcus species $13.3 \%$, Pseudomonas species $6.6 \%$, Proteus species $4.4 \%$, Salmonella species $8.8 \%$ and Klebsiella species $4.4 \%$ being the most frequently isolated. The result showed that the major isolates were similar with slightly higher in cows. Histopathologically, endometrial glands degeneration, sloughing of epithelium, periglandular cuffing and infiltrations of inflammatory cell were some of characteristic changes observed in uterus.

Conclusions: Pathological lesions in reproductive organs in female dromedary camels and cows showed great prevalence, with similarity in bacterial isolates between the two species. The role of each reproductive lesions and bacterial isolates incriminated as causes of reproductive failures in this livestock species needs further investigation.

\section{Background}

Reproduction is a basic prerequisite to efficient livestock production. The fact that productivity of animals largely depends on their reproductive performance, regular and successful reproduction is a key to profitable animal production. Large animals that rarely deliver a live calf are not worth keeping [1]. Therefore, reproductive efficiency is an important facet for achieving maximum return from the animal [2]. Reproductive performance of a given animal depends upon the normal structure and functions of genital organs [3]. However, the physiological process of reproduction could get disrupted due to a variety of factors like nutritional deficiencies, specific and non-specific infections, hormonal abnormalities, immunological malfunctions and environmental stress [4]. Thus, identification of reproductive tract diseases is important, especially, when we dealing with genetically superior animals [5]. Reproductive diseases are considered as an important contributor to the decline in fertility potential in the large farm animals. Generally, in large dairy farm animals, the highest incidence of infertility might result in decreased milk production, treatment costs, extra labor and increased rate of culling [6].

Pathological lesions of the female genital tract are believed to be the major reason for economic losses associated with infertility, culling and slaughtering of cows $[7,8,9]$ and dromedary camels $[10,11]$. In general, female animals 
are culled and sent to slaughterhouse either because they are uneconomic to maintain or else they have chronic or untreatable diseases. Hence, abattoirs are a good source for studying pathological lesions of reproductive organs that are severe enough to cause infertility and even sterility [12]. Moreover, most female reproductive organ pathological lesions lack additional outward manifestations. Therefore, most of these abnormalities can only be diagnosed when the animal is subjected to postmortem examination [13]. Thus, examination of gross and microscopic lesions of genital tract play a central role in the identification of these problems.

Previously, abattoir-based studies on reproductive organs abnormalities of cows have been documented elsewhere in Ethiopia $[1,7,8,9,14]$. According to these studies, ovariobursal adhesion, follicular cyst, luteal cyst, paraovarian cyst, ovarian hypoplasia, vaginitis, cervicitis, hydrosalpinx, pyosalpinx, hydrometra, endometritis, cervical ring hypoplasia and hypoplasia of the uterus were some of the pathological lesions recorded. Similar findings were also been reported from other parts of the world $[15,16,17]$. In Ethiopia, however, limited documented information is available regarding female dromedary camels' reproductive organs lesions [11]. Nevertheless, studies from other parts of the world have reported different reproductive pathological lesions of uterus, ovary, oviduct, cervix and vagina. Among those, the lesions of uterus were the most frequent in almost all studies [6, 18-22].

The inappropriate use of antimicrobials and corticosteroids in the treatment of reproductive disorders or because of retained placenta and other obstetrical procedures in camels and cows favor bacterial contamination of vagina and the subsequent invasion of the uterine environment $[23,24]$. Studies have shown that uterine infection is a significant cause of reproductive failure and infertility in both dromedary camelids [5] and cows [25]. On the other hand, in cows, bacterial pathogens are associated with delayed uterine involution and failure to conceive on one or more cycles in the same season $[24,26]$. The most common and economically important bacteria for uterine infection in both dromedary camelids and cows are Actinomyces species, Escherichia coli, Fusobacterium species, Pasteurella species, Pseudomonas species and Staphylococcus species. [26, 27].

Reproductive inefficiency in animals due to observed pathological lesions of female genitalia causes huge economic loss to farmers. To circumvent the problem, isolation of bacteria from uterus and histopathological investigations of each lesion are critical for diagnosis and management of poor reproductive performances in animals. Most of the studies reported previously were based on gross pathological lesions observation and were done either on cows [7, 8, 9] or female dromedary camels [11]. Comparative studies on pathological lesions in reproductive tract, isolation and identification of bacteria involved in uterine disorder are very few in general and were not yet attempted in Ethiopia. Therefore, to narrow these gaps, the current study was aimed to identify and compare the types and frequencies of reproductive organ pathological lesions between cows and female dromedary camels; describe and characterize gross and microscopic lesions of observed abnormalities. Additionally, the study also tried to isolate and identify aerobic bacteria associated with uterine lesions in both cows and female dromedary camels.

\section{Methods}

\section{Study design, study area and study population}

A cross-sectional study was conducted from November 2016 to May 2017 in Addis Ababa and Adama Municipal abattoirs, and Addis Ababa Akaki Kality camel slaughter house. Addis Ababa municipal abattoir is located at the central part of Addis Ababa whereas Akaki camel slaughter house is located in the south-eastern outskirt of Addis 
Ababa at $20 \mathrm{Km}$ away from the center of Addis Ababa. Adama municipal abattoir is located in Adama town of Oromia regional state at about $99 \mathrm{Km}$ away from the center of Addis Ababa.

The study population were female dromedary camels slaughtered at Addis Ababa Akaki camel slaughter house and cows slaughtered at both Addis Ababa and Adama Municipal abattoirs. All cows and female dromedary camels included in this study were culled due to age or possessing a history of reproductive failure (e.g., repeated breeding, anestrous, abortion, chronic mastitis). In these abattoirs only few or even no cows were slaughtered per day which was also true for female dromedary camels. Taking this in to consideration, the current study was purposively targeted and included all cows slaughtered at both municipal abattoirs and female dromedary camels slaughtered at Akaki camel slaughter house during the study period. Abattoirs were visited for sample collection once every, week for a total of 28 weeks for both cows and female dromedary camels in order to have a sufficient time for sample processing at the laboratory. On average, three to seven animals (for both species) were slaughtered in each abattoir. All slaughtered cows and female dromedary camels were considered for the study. Accordingly, a total of 280 animals (140 female dromedary camels and 140 cows) were slaughtered and examined during the study period for which tissue samples with grossly visible lesions were collected for histopathological and bacteriological examinations. Holstein-Friesian, crossed breed (mixed breed of local Borena and Holstein-Friesian) and local (Borena, Zebu, Arsi-Bale and Harar) breeds of cows were included in to the study.

Age, body condition score and origin of animal were gathered during ante mortem examination. Age of female dromedary camels was estimated by dental examination on the basis of their dental formulas and tartar deposition on the teeth as described in Mohammed et al. [6]. However, cow's age was estimated according to Puck and Soliame [28]. Accordingly, age of animals was categorized as $<5$ years as young, $6-11$ as adult and $>11$ as old in both species of animals. Only mature or post- pubertal animals were evaluated because in Ethiopia pre-pubertal animals are unfit for slaughter due to religious concern). The animals' body condition score (BCS) was evaluated on a scale of 0 to 5 by considering visual examination and fat cover palpation over the animal body following the description by [29]. Therefore, animals were categorized as poor for $\leq 2$, as medium for $\leq 3$ and as good for $\geq 4$ of measurement scale.

\section{Sample collection and processing}

During postmortem examination the entire reproductive tract was carefully removed intact from the pelvic cavity within 10-20 minutes of slaughter, placed on a sterile tray and taken to one corner of the abattoir, where they were visually examined and thoroughly palpated. A total of 280 reproductive tracts (140 from cows and 140 from dromedary camels) were obtained and evaluated during this study period. Each reproductive tract was opened along its longitudinal axis starting from the vagina down to the horns using sterile scissors and was observed for any morphological abnormality, color, odor and consistency [30, 9]. Obvious gross lesions were noted based on their appearance, type, location and frequency of occurrence as previously described by Jenberie et al. [31]. Tissues with grossly visible lesions were sampled for histopathological and bacteriological examinations. Samples for bacteriological examination were collected only from affected uterus of both cows and dromedary camels. For histopathology, a tissue cut of 1-2 cm from the margins of apparently normal and affected parts were collected and fixed in $10 \%$ buffered formalin according to Talukder [32] and transported to National Animal Health Diagnostic Investigation Centre for histopathological processing.

For bacteriological examination, the surface of the uterus with lesions were decontaminated by a flame and tissue fragments from active the borders of lesions at the boundary were collected aseptically using sterile forceps, 
scissors and scalpel blade and placed into screw capped universal bottles containing sterile saline water [33]. Additionally, a sterile cotton swab was used to collect drag swab samples from the active lesion of uterine surface right after visual examination and prior to tissue sample collection. The swab was then placed in a $50 \mathrm{~mL}$ falcon tube containing sterile peptone water for transportation. All the collected samples were labelled, tightly closed and placed in a cool box containing ice packs and transported to the veterinary microbiology laboratory of Addis Ababa University College of Veterinary Medicine and Agriculture for culturing within 1-2hrs of collection. All bacteriological processes were conducted within 6-8hrs of sample collection.

All laboratory bacteriological procedures were performed within 6-10 hrs of sample collection and processed according to previously established protocols [33]. Briefly, tissue samples were cut into pieces and inoculated in to the brain heart infusion broth and aerobically incubated at $37^{\circ} \mathrm{C}$ for $24 \mathrm{hrs}$. Same broth was also inoculated directly with the collected swabs and aerobically incubated at $37^{\circ} \mathrm{C}$ for $24 \mathrm{hrs}$. Tubes were then observed after $24 \mathrm{hrs}$ of incubation for growth (turbidity) and a loop-full of the suspected culture was streaked parallel on sheep blood agar (7\%) and MacConkey agar and incubated aerobically at $37^{\circ} \mathrm{C}$ for another $24 \mathrm{hrs}$. The blood agar plates were checked for presence of growth, hemolysis (types), colony morphology, size and shape. MacConkey agar plates were also checked for presence of growth, lactose fermentation and for colony morphology, size and shape. For primary identification, gram stain, catalase, oxidase and motility tests were conducted. Selective and differential media such as Mannitol salt agar, Edwards medium, Eosine methylene blue and Salmonella shigella agar were used for the suspected samples from the primary test results. After $24 \mathrm{hrs}$ of incubation, the characteristic growth on selective medium was registered after which a colony was then further inoculated in to nutrient broth for further biochemical tests. In general, coagulase, indole, Methyl red (MR), Vogues-Prousker (VP), Citrate, Urease, Lysine and Triple Sugar Iron (TSI) tests were performed as secondary biochemical tests.

For histopathological examination, tissue specimens were fixed in buffered formalin and routinely processed for, paraffin-embedding and hematoxylin-eosin staining in 4 - $5 \mu \mathrm{m}$ sections [32]. Stained slides were examined under the microscope (at 10x, 40x and 100x magnification) using a phase contrast microscope (Nikon, Japan), and photomicrographs were taken.

\section{Data analysis}

A database was created on spreadsheet of Microsoft Excel, 2010 and STATA version 13 statistical software was used for descriptive analysis. Descriptive summary statistics (frequencies and cross-tabulation) were computed for pathological lesions and uterine bacterial isolates prevalence. Uterine bacterial isolates were compared between species using descriptive analysis. Qualitative method was used to describe gross and histopathological lesions and findings.

\section{Results}

The detail of observed lesion types with frequencies was shown on Table 1, 2 and 3 below. Of a total of 280 reproductive tracts (140 for each group of cows and dromedaries), 48 (34.2\%) and 51 (36.4\%) diseased reproductive tracts were observed in female dromedary camels and cows, respectively. Comparatively, the most frequently observed reproductive tract lesions in dromedary camels were uterine abnormalities $21.4 \%$ followed by ovarian lesions $7.14 \%$ (Figure 1). However, in cows, ovarian lesions were the most $16.4 \%$ frequently observed followed by uterine lesions $14.2 \%$. Vaginal lesions were less prevalent, but were observed more frequently in dromedary camels $(2.85 \%)$ than cows $(1.42 \%)$ (Figure 1$)$. The prevalence of follicular cyst in both species of 
animals was higher in animals with good body condition as compared to animals with medium or poor body condition (Table 1). The result also indicated that old female dromedary camels and cows were more prone to chronic endometritis than other age groups (Table 2).

\section{Ovarian and oviductal lesions}

Different ovarian abnormalities were observed in $23(16.4 \%)$ and $10(7.14 \%)$ of examined cows and female dromedary camels, respectively. Collectively, follicular cyst, luteal cyst, inactive ovary, paraovarian cyst, ovarian bursal adhesion, oopharitis and hydrobursitis were observed (Table 1). Ovarian bursal adhesion and oopharitis were observed only cows whereas hydrobursitis was seen only in dromedary camel.

Table 1: Frequency (\%) of ovarian lesions

\begin{tabular}{lllllllll}
\hline Variables & Category & $\begin{array}{l}\text { Follicular } \\
\text { cyst }\end{array}$ & $\begin{array}{l}\text { Luteal } \\
\text { cyst }\end{array}$ & $\begin{array}{l}\text { Paraovarian } \\
\text { cyst }\end{array}$ & $\begin{array}{l}\text { Inactive } \\
\text { ovary }\end{array}$ & $\begin{array}{l}\text { Ovarian- } \\
\text { bursal } \\
\text { adhesion }\end{array}$ & Oophoritis & $\begin{array}{l}\text { Ovarian } \\
\text { hydrobursitis }\end{array}$ \\
\hline Species & Cow & $6(26.1)$ & $3(13)$ & $2(8.7)$ & $4(17.4)$ & $7(30.4)$ & $1(4.3)$ & 0 \\
& Camel & $4(40)$ & $2(20)$ & $2(20)$ & $1(10)$ & 0 & 0 & $1(10)$ \\
Age & Young & $1(20)$ & $1(20)$ & $1(20)$ & $1(20)$ & $1(20)$ & 0 & 0 \\
& Adult & $7(38.9)$ & $2(11.1)$ & $3(16.7)$ & $3(16.7)$ & $3(16.7)$ & 0 & 0 \\
& Old & $2(20)$ & $2(20)$ & 0 & $1(10)$ & $3(30)$ & $1(10)$ & $1(10)$ \\
BCS & Poor & $1(10)$ & $2(20)$ & 0 & $4(40)$ & $2(20)$ & 0 & $1(10)$ \\
& Medium & $1(14.3)$ & $1(14.3)$ & $3(42.9)$ & 0 & $1(14.3)$ & $1(14.3)$ & 0 \\
& Good & $8(50)$ & $2(12.5)$ & $1(6.3)$ & $1(6.3)$ & $4(25)$ & 0 & 0 \\
\hline
\end{tabular}

Follicular cysts were seen in $26.1 \%$ and $40 \%$ of ovarian lesions observed in cows and dromedary camels, respectively. The lesions were unilateral in both species. Three of them were on the right ovary while the other three were on the left ovary in cows; in the dromedary camel only one was on the right and the other three were on left ovary. Macroscopically, most of the cysts were spherical in shape and occupied the ovarian cortex in both species. Their diameters were ranged from $30 \mathrm{~mm}$ to $55 \mathrm{~mm}$ and the walls of the cysts were thin, slightly opaque and had straw colored serous fluid. One follicular cyst in a cow was accompanied by an ipsilateral inactive ovary and endometritis (Figure 2A). Microscopically, the follicular cysts were lined by few layers of granulosa cells, as large portion of the granulosa cells were degenerated due to the pressure exerted by the follicular fluids. It was difficult to differentiate the theca interna from the externa as the cells were compressed by the fluid pressure (Figure 2B). Moreover, larger cysts caused pressure atrophy of the adjacent ovarian tissues and led the ovum and the surrounding cells completely degenerated or absent.

Among the observed ovarian lesions, luteal cysts were seen in $13 \%$ and $20 \%$ of examined cows and dromedary camels, respectively. In cows, two cysts were on the right ovary and one on the left. In dromedary camels, all cysts were observed on the right ovary. Macroscopically, the luteal cysts were thick walled, opaque and have meat like consistency. The wall of the cyst was lined by a whitish brown or yellow membrane. Furthermore, in cows, all the 
luteal cysts appeared as a single rounded mass on the surface of the ovary. In one camel multiple luteal cyst were observed. The diameter of the luteal cysts ranged from 20-25 mm and microscopically, the wall of the luteal cysts was formed from thick layer of lutein cells and granulosa cells with high lipid content. They contained homogenous eosinophilic structure mixed with some luteal cells in the lumens.

The frequency of occurrence of paraovarian cysts was $8.7 \%$ in cows and $20 \%$ in dromedary camels. Macroscopically, the cysts were detected unilaterally only on the left ovary in both species. The cysts were located either in mesovarium or in mesosalpinx ligament. These cysts were 10-20 mm in diameter and transparent, having thin wall and contained clear watery fluid. Hydrobursitis was observed in $10 \%$ of examined dromedary camels but, none in cows. The size of the affected bursa was about $5 \times 6.4 \mathrm{~cm}$ and the affection was unilateral. Moreover, the bursa was having about $25 \mathrm{ml}$ of accumulated watery and yellowish color fluid.

The frequency of occurrence of inactive ovary was $17.4 \%$ in cows and $10 \%$ in dromedary camels. It was bilateral and the ovary was very small, oval in shape and measured $1 \mathrm{~cm}$ by $1 \mathrm{~cm}$ in camel. In cows, all were unilateral with three of them on the right and one on the left ovary. The size varies from $1.6 \mathrm{~cm}$ by $1.1 \mathrm{~cm}$ to $1.5 \mathrm{~cm}$ by $1.0 \mathrm{~cm}$. Macroscopically the ovaries were smaller in size, firmer in consistency and contained very small follicles on the surface of non-affected part. Microscopically, excessive fibrous connective tissue proliferation with complete absence of follicular or luteal developments was seen (Figure $3 \mathrm{~A}$ and B)

One case (4.3\%) of oophoritis was observed in the examined cows but was not observed in any of the examined dromedary camels. This lesion might be related to the existence of ovarian bursal adhesion as they co-existed. Macroscopically, the ovary was hyperemic and slightly swollen. Microscopically, the ovarian medulla was infiltrated by inflammatory cells (Figure. $4 \mathrm{~A}$ and $\mathrm{B}$ ).

Ovariobursal adhesion was the most frequently observed (30.4\%) ovarian lesions in cows. However, none was observed in dromedary camels. Except for a single adhesion which was bilateral, all examined lesions were unilateral. Four of the adhesions were on the right and two on the left ovary. In one case, ovariobursal adhesion was co-existed with oophoritis. Macroscopically, the ovaries were found adherent to the bursa and surrounded by a layer of connective tissue. The severity of adhesions varied from case to case. In five cases the adhesions were mild with sparse strands of connective tissue between the ovary and bursa while in two cases, the adhesions were intense in which the ovaries were completely encapsulated in thick fibrous connective tissues.

Hemosalpinx was observed in one dromedary camel and three cows. In dromedary camel, it was unilateral and observed in the right oviduct. However, it was bilateral in one cow and unilateral in two cows and seen in the right oviduct. Macroscopically, in both species the oviduct was slightly enlarged in size and the mucosa was hyperemic and filled with blood. Microscopically, hyperplasia of the lining epithelium and congestion of blood vessels with inflammatory cellular infiltration were noticed (Figure 5). Pyosalpinx was detected in one camel and two cows. Macroscopically, the affection was bilateral in both species. Moreover, the oviduct was enlarged and distended with pus. In one cow pyosalpinx was accompanied with suppurative endometritis.

\section{Uterine lesions}

Uterine lesions were the most frequently observed lesions (21.4\%) in dromedary camels, however, it was the second most frequently observed reproductive lesion in cows with a frequency of 20 (14.2\%). Except for leiomyoma, microscopically all uterine lesions were inflammatory in both species. Acute endometritis, chronic endometritis and 
catarrhal endometritis were commonly observed in both species of animals. However, suppurssative endometritis was observed only in cow's uteri (Table 2).

Table 2: Frequency (\%) of uterine lesions

\begin{tabular}{llllllll}
\hline riables & Category & Cervicitis & $\begin{array}{l}\text { Acute } \\
\text { Endometiritis }\end{array}$ & $\begin{array}{l}\text { Chronic } \\
\text { Endometiritis }\end{array}$ & $\begin{array}{l}\text { Catarrhal } \\
\text { Endometiritis }\end{array}$ & $\begin{array}{l}\text { Suppurative } \\
\text { Endometritis }\end{array}$ & Leiomyoma \\
\hline scies & Cow & $2(1.42)$ & $9(42.9)$ & $7(33.3)$ & $2(9.5)$ & $2(9.5)$ & $1(4.8)$ \\
& Camel & $2(1.42)$ & $12(40)$ & $16(53.3)$ & $2(6.7)$ & 0 & 0 \\
e & Young & 0 & $2(25)$ & $5(62.5)$ & $1(12.5)$ & 0 & 0 \\
& Adult & $2(1.52)$ & $11(61.1)$ & $5(27.8)$ & 0 & $2(11.1)$ & 0 \\
& Old & $2(1.67)$ & $8(32)$ & $13(52)$ & $3(12)$ & 0 & $1(4)$ \\
S & Poor & $1(1.13)$ & $7(35)$ & $7(35)$ & $3(15)$ & $2(10)$ & $1(5)$ \\
& Medium & $1(1.75$ & $5(50)$ & $5(50)$ & 0 & 0 & 0 \\
\end{tabular}

Acute endometritis was more frequent in examined cows $42.9 \%$ than dromedary camels $40 \%$ (Table 2 ). Acute endometritis was accompanied by luteal cyst in two of the dromedary camels. Macroscopically, the affected uteri were enlarged and the mucosa was either severely congested (red brown) or was severely reddened (Figure 6). Furthermore, thick blood tinged exudates were seen in the uterine lumen of three dromedary camels and one cow. Microscopically, endometrial epithelia were necrotized and sloughed in most cases with either congestion or hyperemia of endometrial blood vessels especially, in basilar endometrial region. Moreover, polymorphonuclear cells, mostly neutrophils, were infiltrating the endometrium. Excessive peri-glandular cuffing of cells and atrophy of endometrial glands were characteristics of acute endometritis.

Suppurative endometritis were observed only in cows with a frequency of $9.5 \%$. Macroscopically, the endometrium was congested and covered with thick creamy white pus. The lesions were also further expanded to uterine horn but no purulent material was observed in uterine horn. Microscopically, suppurative endometritis was characterized by infiltration of neutrophils into the endometrium with severe congestion of blood vessels and distortion of some endometrial glands. Catarrhal endometritis was observed in two dromedary camels and two cows. Macroscopically, the uterus was enlarged and its mucosa was slightly congested, edematous and was covered by thick catarrhal exudates. In one camel, the catarrhal exudates further expanded to cervix and vaginal mucosa and discharged to outward. The microscopic examination showed congestion of endometrial blood vessels, lymphocytic infiltration in the mucosa and sub-mucosa with alternative areas of epithelial desquamation and hyperplasia of lining epithelium. Degenerations of endometrial glands were also seen (Figure 7).

Chronic endometritis was more frequent in dromedary camels (53.3\%) than cows (33.3\%) (Table 2). In one cow with chronic endometritis there was a concomitant luteal cyst, vaginitis and cervicitis. Macroscopically, most of the uteri with chronic endometritis were thick, doughy, rigid, and their mucosa was severely congested. In one dromedary camel with chronic endometritis the uterus was severely congested, with corrugation of the perimetrium and dark 
brown hemorrhage on the external surface (Figure. $8 \mathrm{~A}$ and B). Microscopically, the mesothelium of this uterus was hyperplastic with polypoid like projections and diffuse thickening of basal fibrous connective tissue. Most of the uteri affected by chronic endometritis were characterized by endometrial glandular degeneration, infiltration of mononuclear inflammatory cells, mostly lymphocytes, macrophages and to a lesser extent neutrophils. In some case hyperplasia of endometrial epithelium was observed (Figure $8 \mathrm{C}$ and D).

Only one uterine tumor was observed in a cow and was considered as uterine leiomyoma whereas none was observed in dromedary camels. Macroscopically, the neoplasm was well-circumscribed, firmly attached on the body of the uterus with a diameter of $10 \mathrm{~cm}$ and a whorl-like and trabeculated on cut surface. Microscopically, the leiomyoma was comprised of smooth muscle cells and connective tissue components. Largely, composed of interlacing (interweaving) bundles of smooth muscle fibers with acidophilic cytoplasm and elongated and rounded blunt ending nuclei. The fibers were usually fusiform or stellate in shape, possessed large, ovoid to elongated nuclei and sometimes multiple nucleoli. Slight pleomorphism and little mitotic activity was also observed (Figure 9).

\section{Cervico-vaginal lesions}

Cervicitis was seen in both species of animals with a frequency of $1.42 \%$ in each species of animals. In general, cervical lesions were observed with low incidence than the rest of reproductive organ lesions in both species (Table 3). In both cows and dromedary camels, all observed cervicitis were associated with endometritis. Macroscopically, the cervix was slightly enlarged with congested and edematous mucosa that was covered with whitish viscous exudates.

Table 3: Frequency (\%) of oviductal and vaginal lesion

\begin{tabular}{llllll}
\hline Variables & Category & Hemosalpinx & Pyosalpinx & Vaginitis & Vaginal myositis \\
\hline Species & Cow & $2(50)$ & $2(50)$ & $2(1.42)$ & 0 \\
& Camel & $1(50)$ & $1(50)$ & $1(25)$ & $3(75)$ \\
Age & Young & 0 & 0 & 0 & 0 \\
& Adult & $2(1.52)$ & $2(1.52)$ & $2(1.52)$ & $2(1.52)$ \\
& Old & $2(1.66)$ & $1(0.83)$ & $1(0.83)$ & $1(0.83)$ \\
BCS & Poor & $2(2.27)$ & $1(1.13)$ & $1(1.13)$ & $2(2.27)$ \\
& Medium & 0 & $1(1.75)$ & $1(1.75)$ & 0 \\
& Good & $2(1.48)$ & $1(0.74)$ & $1(0.74)$ & $1(0.74)$ \\
\hline
\end{tabular}

Generally, vaginal lesions were more frequently observed in dromedary camels (2.9\%) than cows (1.42\%). Vaginitis and vaginal lymphocytic myositis were the two kinds of vaginal lesions observed in dromedary camels with a frequency of $25 \%$ and $75 \%$, respectively. However, only vaginitis was observed in examined cows (Table 3 ). Macroscopically, the mucosa appeared slightly swollen and showed diffuse, non-homogeneous congestion and hyperemia. Moreover, in one of the three camels in which vaginal lymphocytic myositis was observed, the lesion was consistent with chronic endometritis. Macroscopically, in all vaginal lymphocytic myositis cases, the lesion was appeared as a single, large sized $(7-10 \mathrm{~cm}$ diameter) mass on the lateral wall of the vagina just cranial to 
vulvar commissure on palpation the mass was soft. Microscopically, these lesions were characterized by huge lymphocyte infiltration into the smooth muscle fibers and some muscular degeneration. In some regions, the muscle fibers necrotized and connective tissues were proliferated (Figure 10).

\section{Bacterial isolates from the uterine lesions of cows and camels}

Fifty uterine tissue samples (30 from camels and 20 from cows) with acute, chronic, catarrhal and suppurative endometritis were cultured aerobically for bacterial isolation, 48 of which lead to bacterial isolates. Except for few bacteria which were isolated as pure culture, the majority of the isolates presented a mix bacterial population. A total of 101 isolates were recovered, 56 out of them were from cows and 45 from female dromedary camels. Among bacterial pathogens isolated from cows, prevalence was distributed as follows; Staphylococcus spp $28.5 \%$, Streptococci spp 19.6\%, Coynebacterium spp 8.9\%, Escherichia coli 26.8\%, Salmonella spp 10.7\% and Klebsiella spp $5.4 \%$. In dromedary camels the most common isolates included E. coli $35.5 \%$, Staphylococcus spp $26.6 \%$, Streptococcus spp 3.3\%, Pseudomonas spp 6.6 \% , Proteus spp 4.4\%, Salmonella spp 8.8\% and Klebsiella spp $4.4 \%$. The common bacterial isolates identified from both species (Staphylococcus spp, Streptococcus spp, Escherichia coli, Salmonella spp and Klebsiella spp) accounted for more than $90 \%$ of isolated bacteria. Moreover, Pseudomonas spp and Proteus spp were only isolated from camel uteri whereas Corynebacterium spp was only isolated from cows' uteri.

\section{Discussion}

Reproductive abnormalities play an important role in animal breeding either by causing infertility or sterility, and thus inflict heavy economic losses to the livestock owners. Animals with reproductive problems and low milk production are usually culled. For minimization of these losses, important disorders of genital organs and their incidence must be defined [34]. Although previous reports claimed that camels are resistant to various disease conditions [35], the current study suggests that most of the reproductive disorders have a similar occurrence in both species of animals. This is in agreement with previous studies in which it was documented that camels are quite as susceptible as other livestock species to various disease conditions [36, 37].

In this study the prevalence of uterine lesion was greater in dromedary camels than in cows, even if a previous report showed an opposite trend [27]. This variation among the different studies might be attributed to differences in season, management, geographical environment, level of nutrition and health management of animals. In the current study endometritis was the major uterine lesion observed in dromedary camels. This could be attributed to different factors like repeated insults of the uterus due to improper mating practices [38], postpartum complications and unsanitary gynecological manipulations [5]. Moreover, in line with the above statement, in the current study almost all of the examined animals were brought to the abattoirs and slaughter houses because they were having one or more reproductive problems and are no more productive.

In the present study occurrences of chronic endometritis varied within age groups in either female dromedary camels or cows. Old female dromedary camels and cows were positive to chronic endometritis than other age groups of animals which was in accordance with the study report of Waheed et al. [39]. This might be due to the fact that older animals are considered to be associated with increased frequency of mating, parturitions and/or repeated postpartum complications than other age groups. Similar to the present study result, various previous studies were also reported uterine leiomyoma in cows [40, 41 and 42]. Although the etiology of the uterine leiomyoma is not clearly known [40], in the current study it was found that the leiomyoma was composed of 
smooth muscle neoplastic cells accompanied by varying quantities of connective tissue lacking glandular component. This was in agreement with the report of Kennedy and Miller [43]. Even if there was no observed cases of leiomyoma in camels in the current study, however, previous studies indicated that female dromedary camels may also develop leiomyoma [10].

In the present study the prevalence of ovarian lesions of cows were almost twice compared to dromedary camels. This might be attributed to the high production potential of the Holstein Friesian breeds of cows and Holstein Friesian cross-breed cows which were highly selected for milk yield. According to the reports of Opsomer et al. [44] and Butler [45], dairy cow's experiences higher that were exposed to negative energy balance especially at early lactation and with higher milk yield were considered to be at risk of developing ovarian disorders. As to our knowledge, most of the dairy cows in Ethiopia were owned by small holder farmers with poor management practices in which exposure to different reproductive problems is inevitable.

The present study showed higher prevalence of follicular cysts in dromedary camels as compared to cows. This might be associated to the fact that dromedary camels ordinarily are liable to develop follicular ovarian cysts in the absence of coitus [46]. Additionally, this can also be associated to various influencing factors like level of milk production; feeding, management and exercise which might affect the prevalence of cystic follicle in either of the animal species [47]. Though it is difficult to determine the exact cause of ovarian follicular cysts, it can be realized that they develop when one or more follicles fail to ovulate and subsequently fail to regress maintaining growth and steroidogenesis [48, 49].

In this study the prevalence of follicular cyst in both species of animals was found to be vary in relation to the different body condition scores in which the frequency of development of follicular cyst was found to be higher in animals with good body condition. This was in agreement with earlier reports by Tibary and Anouassi [23] and Abalti et al. [7] in which camels and zebu cattle with ovarian cysts had a general body condition fair to good. Furthermore, it is found documented elsewhere that dairy animals that were exposed to negative energy balance especially at early lactation and with higher milk yield were considered to be at risk of developing ovarian cysts [44, 45]. Microscopically, degeneration of surrounding theca and granulosa cells were seen in both species which was comparable with various previous reports $[10,11,20,34]$.

In the present study the prevalence of luteal cyst was lower than that of the follicular cyst in both species of animals. This might be due to the fact that luteal cysts originate from luteinization of follicular cyst, which results from luteinization of granulosa cells in the absence of ovulation [10]. Moreover, they are often considered to be a later form of ovarian follicular cysts and therefore the causes pertaining to follicular cysts can also be considered the original causes of luteal cysts [49]. The macroscopic and microscopic findings of the present study was in line with previous reports $[10,20]$.

In this study ovarian bursal adhesion was only seen in cows. Although there was no history of pregnancy complications in the current study, previous study reports indicated that extreme adhesions have probably resulted from pregnancy complications that include retained fetal membranes and endometritis [50]. Furthermore, this lesion can also result from hemorrhage due to harsh manipulation of the ovaries or attempts to rupture an ovulatory hemorrhagic follicle or also may result from oophoritis, ovarian hydrobursitis and peritonitis [23]. The prevalence of ovarian bursal adhesion observed in this study was in agreement with previous reports of $[7,9,17]$. However, it was higher than the reported by Hatipoglu et al. [34]. The variation observed might be attributed to the difference in breed, management and level of nutrition. 
In the current study para-ovarian cysts were more observed in camels as compared to cows. Para-ovarian cysts are suspected to arise from persistent embryonic structures which are, representing vestiges of wolfian ducts [20]. Paraovarian cysts in cows are considered to be not interfere with the reproductive performance of the animal unless it leads to compression of the lumen of the oviduct [51,52]. The reason why inactive ovary was observed with low frequency in dromedary camels than cows in this study might be related to seasonal breeding behavior of the camelids and the current study was carried out during which most camels were cyclic. The study by Monaco et al. [53] also justified that peak sexual activity of dromedary camel ranges from November to February. Moreover, microscopically, complete absence of follicular or luteal development and excessive fibrous connective tissues proliferation was observed which was in agreement with previous reports $[10,11]$.

In this study oophoritis was observed only in cows and was in line with the report of camel oophoritis by Mahmoud et al. [20]. As it is documented by Fathalla et al. [54], oophoritis seems to be a rare pathological condition of bovine ovary while peri-oophoritis is commonly found. The prevalence of hydrobursitis in camel in this study was approximately similar to that of Al-Afaleq et al. [19]. However, it was lower than the report by Ali et al. [18] and Mohammed et al. [6]. The macroscopic findings of this lesion were in line with that of Mohammed et al. [6]. Available sources indicated that the incidence of hydrobursitis is relatively higher in animals with a background of reproductive failure which is also true in our cases in which almost all of the slaughtered animals were with a history of reproductive failure [55].

The frequency of oviduct affections in the present study was low in both species. In this study hemosalpinx was observed in both animal species and was in agreement with previous reports $[26,56]$. Pyosalpinx accompanying a suppurative endometritis agrees with the report by Kennedy and Miller [43] who associated pyosalpinx with ascending infections. Moreover, Tibary and Anouassi [57] considered that untreated uterine infections can lead to irreversible changes in oviducts thus resulting in sterility due to occlusion. Regarding to the detected pathological changes in the cervix, the low frequency of cervical affections may be due to good defense action of the mucous secreting epithelium of the cervix against bacterial invasion [58]. All the observed cervicitis in the present study were associated with uterine affection or inflammation of endometrium and this finding was in line with the report by Shawky et al. [10].

The pathological changes of vagina of cows and dromedary camels observed herein were less frequent compared to uterine and ovarian lesions. This low frequency might be attributed to various factors of which the protective effect of stratified squamous epithelium of vaginal mucosa which proliferates and matures under the influence of estrogen and become more resistant to infection is of great concern. Furthermore, local production of lactic acid which deposit into the epithelium is also considered [58]. The relatively higher frequency of vaginal lesions in female dromedary camels than in cows might be associated to traumatic injury during coitus [57]. Furthermore, Ali et al. [5] justified that the ethno-veterinary practices by herdsmen using unusual substances, like dates, black seeds, and salts might be irritant to the mucus membrane and leads to vaginal lesions in dromedary camels.

The current study also tried to isolate possible bacterial species from the affected uterus of both animal species and observed that the bacteria isolated from dromedary camel's uteri were similar to those in cows. This might be associated with the camels husbandry practices in many parts of camel producing areas in Ethiopia and also other parts of the world, which allow them to graze together with other ruminants and mingling with them at watering points or market places, thereby creating conducive environment facilitating transmission of infectious pathogens circulating among livestock species cohabiting within the same ecologic zone $[59,60,61]$. The bacteria isolated from endometritis might be suspected as the main causes of endometritis in both species. This finding was in 
support of the report by Tibary [62] who reported resistance of the uterus to infection and its ability to rid itself of microorganisms was diminished in the presence of degenerative changes in the endometrium.

The most common bacterial species isolated from cows and dromedary camels uterine with endometritis were Staphylococcus, Streptococcus, Salmonella and Klebsiella species and Escherichia coli. This finding agrees with report of Mshelia et al. [37]. Most of the aforementioned bacterial species were attributed to the majority of the clinical reproductive disorders [63]. Proteus and Pseudomonas species were isolated only from uterine lesion of dromedary camels and was in agreement with previous reports by Simenew et al. [11] and Al-Afaleq et al. [19].

\section{Conclusions}

This study reports one or more pathological abnormalities in reproductive organs of dromedary camels and cows slaughtered at Addis Ababa and Adama Municipal abattoirs and Akaki slaughter house. Uterine lesions were the major pathological disorders observed in dromedary camels while ovarian lesions were the most frequent in cows. Important bacterial species were isolated from uterine lesions of both animal species examined. These observed microbial agents are considered important causes of uterine disorders in these animal species and have to be investigated in susceptible females during the evaluation of animals pre-breeding status. Also, most of the pathological reproductive abnormalities detected in this study might be a cause of infertility in these animals being the major reason for them to be considered for slaughtering. Thus, it is important to submit that female animals to a breeding evaluation that should include bacteriological and histological evaluation, before the breeding season, particularly if infertility is suspected, to improve production outcome. Besides, reproductive health management, especially, targeting the postpartum and critical periods, should be implemented. Moreover, studies involving wider number of abattoirs and animals and correlation between individual's reproductive lesions and hormonal disorders should be conducted to add with more figurative results. Furthermore, there is a need for panoptic studies basing uterine cytobrush and uterine biopsy to correlate bacterial isolates with uterine lesions. Additionally, trainings for concerned veterinarians, technicians and animal owners on reproductive health and management for proper intervention mechanisms should be implemented.

\section{Declarations}

\section{Ethics approval and consent to participate}

Study was approved by College Review Board of Addis Ababa University College of Veterinary Medicine and oral consent was obtained from each abattoirs manager board before sampling.

\section{Consent for publication}

Not applicable

\section{Availability of data and material}

All data supporting the findings of this study are available within the article.

\section{Competing interest}

We declare that there is no competing interest. 


\section{Funding}

This study was financially supported by Addis Ababa University Research and Technology transfer thematic research project entitled as "Reproductive Health Management and Dairy Technology RD/LT-038/15".

\section{Author's contribution}

AMG and TDA generate and process the research idea and developed the proposal and analyzed the bacteriological and histopathological data and handled statistical analysis. AMG and TGG collected, processed and manipulated the samples. BGB and NTD performed the histopathological investigations. GCH edited and organized the manuscript.

All the authors have read and approved the manuscript for publication.

\section{Acknowledgements}

The authors acknowledge Addis Ababa University Research and Technology transfer thematic research project entitled as "Reproductive Health Management and Dairy Technology RD/LT-038/15" for providing financial support.

We are very grateful for Mr. Tewdros Arega and Mr. Solomon Getachew in the department of veterinary pathology from National Animal Health and Diagnostic and Investigation center, for their technical assistance in the histopathology laboratory work.

We also thank Addis Ababa, Adama municipality Abattoirs and Akaki slaughter house workers for their kind reception, preparing equipment's and materials for the success of this work and good willing to use their Abattoirs.

\section{References}

[1] Arata MA. A Gross Morphological Study of Genital Organs from female Zebu Cattle in and around Jimma town (South-West Ethiopia). Int J Agro Vet and Medi Sci. 2015: 9; 300-303.

[2] Khaton R, Sarder M, Gofur M. Biometrical Studies of Reproductive Organs of Dairy Cows of Different Genotypes in Bangladesh. Asian J Ani Sci. 2015: 9; 388-395.

[3] Siddiqui HU, Ahmad A, Khan MZ. Biometrical studies of testes of ram. J Agri Soci Sci. 2005: 1; 78-79.

[4] Khanvilkar AV, Samant SR, Ambore BN. Reproduction in Camel. J Vet World. 2009: 2; $72-73$.

[5] Ali A, Al-sobayil FA, Tharwat M, Al-Hawas A, Ahmed AF. Causes of infertility in female camels (Camelus dromedarius) in Middle of Saudi Arabia. J Agri Sci and Vet med. 2010: 2; 59-69.

[6] Mohammed HB, Bernard F, Rachid K. Reproductive abnormalities in female camel (camelus dromedarius) in algeria: Relationship with age, season, breed and body condition score. J Camel Prac Res. 2014: 22; 1-7.

[7] Abalti A, Bekana M, Woldemeskel M, Lobago F. Female genital tract abnormalities of Zebu cattle slaughtered at Bahir-Dar Town, North-Western Ethiopia. J Trop Ani Health Prod. 2006: 38; 505-510

[8] Simenew K, Bekana M, Fikre L, Tilahun Z, Wondu M. Major gross reproductive tract abnormalities in female cattle slaughtered at sululta slaughterhouse in Ethiopia. Glo Vet J. 2011: 6; 506-513. 
[9] Mekibib B, Desta T, Tesfaye D. Gross pathological changes in the reproductive tracts of cows slaughtered at two abattoirs in Southern Ethiopia. J Vet Med and Ani Health. 2013: 46-50.

[10] Shawky AM, Ahmed AT, Mona FI. An abattoir survey of female genital disorders of camels (Camelus Dromedaries) in Kalyoubia, Egypt. $1^{\text {st }}$ Annual Conference Moshtohor. 2004: 1; 342-356.

[11] Simenew K, Moa M, Ashenafi F, Tilaye D, Fekadu R et al. Pathological and Bacteriological Study on Abnormalities of Female Internal Reproductive Organ of Camelus dromedarius Slaughtered at Akaki Abattoir, Ethiopia. Am-Eur J Sci Res. 2015: 10; 193-202

[12] Thrusfield M. Abattoir as Source of Data Veterinary Epidemiology 2nd edn. Black Well Science Ltd. Cambridge, USA, 1995: 146-148.

[13] Buregelt CD. Color atlas of reproductive pathology of domestic animals. 1997; Mosby, Philadelphia.

[14] Gebrekidan B, Yilma T, Solmon F. Major causes of slaughter of female cattle in Addis Ababa Abattoir enterprise, Ethiopia. Ind J Ani Res. 2009: 43; 271-274.

[15] Chaudhari SU, Pau-Bakko B. Reproductive status, pregnancy wastage and incidence of gross genital abnormalities in cows slaughtered at Maidughuri abattoir, Niger. Pak Vet J. 2000: 20; 203-205.

[16] Tafti A, Darahshiri M. Studies on the uterine abnormalities of slaughtered non-pregnant adult cows. Ind Vet J. 2000: 77; 1059-1062.

[17] Ali R, Raza AM, Tabbar A, Rasool HM. Pathological studies on reproductive organs of zebu cow. J Agri and Soc Sci: 2006: 2; 91-95.

[18] Ali A, Mehana EE, Ahmed AF, El-Tookhy O, Al-Sobayil A et al. Ovarian hydrobursitis in female camels (Camelus dromedarius): clinical findings, histopathology and fertility after unilateral surgical ablation. Therio. 2011: 76; 492499.

[19] Al-Afaleq Al, Hegazy AA, Hussein MF, Al-Dughaym AM. Pathological disorders of the female reproductive system in slaughtered camels (Camelus dromedarius) in Saudi Arabia. J Comp Clin Path. 2012: 21; $245-251$.

[20] Mahmoud MH, Fahad AA, Mostafa MH. Pathologic Studies on ovarian abnormalities in Nagas (Camelus Dromedarius) in Al-Ahsa, Saudi Arabia. Sci J King Faisal Univ. 2011: 12; 265-276.

[21] Wajid SJ. A Pathological Abattoir Survey of the Reproductive Tracts of non-pregnant Camels (Camelus dromedaries) in Iraq. J Phar and Bio Sci. 2015: 10; 84-90.

[22] Mustafa MY, Chaudhry HR, Chaudhry M, Rashid HM, Khan SA. Biometry and Pathology of Internal Genital Organs of Female Camel (Camelus Dromedarius) in Lahore, Pakistan. Imper J Interdisc Res. 2016: 2; $2454-1362$.

[23] Tibary A, Anouassi A. Retrospective study on an unusual form of ovario-bursal pathology in the camel (Camelus dromedarius). Therio. 2001: 56; 415-424.

[24] Gani MO, Amin MM, Alam MG, Kayesh ME, Karim MR et al. Bacterial flora associated with repeats breeding and uterine infections in dairy cows. Bangl J Vet Med. 2008: 6; 79-86. 
[25] Hasan MA, Mamun AA, Uddin AA, Zakir MD, Hassan MZ et al. Investigation into gyneco-pathological disorders and identification of associated bacteria from the genital organs of cows in Dinajpur, Bangladish. J Adv Vet and Ani Res. 2015: 2; 165-169.

[26] Azawi OI. Postpartum uterine infection in cattle. Ani Repro Sci. 2008: 105; 187-208.

[27] Mshelia GD, Abba Y, Voltaire YA, Akpojie G, Mohammed H et al. Comparative uterine bacteriology and pathology of camels (Camelus dromedarius) and cows in north-eastern Nigeria. J Comp Clin Path. 2012: 11; $234-261$.

[28] Puck A, Soliame R. Dairy Cattle Husbandry. $2^{\text {nd }}$ edit., Agromisa foundation, Wagenineger, Netherland. 2004:7075.

[29] Nicholson MJ, Butterwort MH. A Guide to Condition Scoring of Zebu Cattle. International Livestock Reserch Center for Africa, Addis Ababa, Ethiopia. 1998.

[30] Feyissa T, Bekana M. A gross morphological abattoir study of genital organs from female crosses breed and Zebu cattle. Israel J Vet Med. 2000: 55; 83-87.

[31] Jenberie S, Awol N, Ayelet G, Gelaye E, Negussie H et al. Gross and histopathological studies on pulmonary lesions of camel (Camelus dromedarius) slaughtered at Addis Ababa abattoir, Ethiopia. J Trop Ani Health Prod. 2012: 44; 849-854.

[32] Talukder S. Histopathology techniques, tissue processing and staining. 2007: http://www.talukderb.com [33] Quinn PJ, Markey BK, Carter ME, Donnelley WJ, Leonard FC. Clinical Veterinary Microbiology disease. Black well, London, 2004: 76.

[34] Hatipoglu F, Kiran MM, Ortatatli M, Erer H, Çiftçl KM. An abattoir study of genital pathology in cows: Department of Pathology Faculty of Veterinary Medicine University of Selcuk. Rev de Méd Vét. 2002: 153; $29-33$.

[35] Dalling T, Robertson A, Boddie G, Spruell J. Diseases of camels. In: The international encyclopedia of veterinary medicine. W Green and Son Edinburgh, 1998: 585.

[36] Abbas B and Agab H. A review of camel brucellosis. J Prev Vet Med. 2002: 55; 47-56.

[37] Gwida M, El-Gohary A, Melzer F, Khan I, Rosler U. Brucellosis in camels. J Res Vet Sci. 2011: http://doi:10.1016/ 05002

[38] Tibary A, Fite C, Anouassi, Sghiri A. Infectious causes of reproductive loss in camelids. Therio. 2006: 66; 633647

[39] Waheed MM, Hamouda MA, Al-Dughaym AM. Uterine histopathological findings of infertile female camels (Camelus dromedarius). J Camel Pract Res. 2009: 16; 1-7.

[40] Sendag S, Cetina Y, Alana M, Ilhana F, Eskia F et al. "Cervical leiomyoma in dairy cattle”. J Ani Repro Sci. 2008: $103 ; 355-350$.

[41] Timurkaan N, Aydin M, Yilmaz F, Cevik A. Vaginal fibro-leiomyoma in a cow: a case report. J Vet Med. 2009: 54; $138-141$. 
[42] Arvind S, Adarsh K, Sheikh I, Pankaj S, Rajesh K. "Ultrasonographic, Surgical, and Histopathological Findings of a Uterine Leiomyoma in a Cow." Case Reports in Vet Med. 2012: 42; 4-8.

[43] Kennedy PC, Miller RB. The Female Genital System. In: Pathology of Domestic Animals, Jubb, Kennedy, Palmer Eds., Academic Press, NewYork, 1993: 349-470.

[44] Opsomer G, Grohn YT, Hertl J, Coryn M, Deluyker H et al. Risk factors for post-partum ovarian dysfunction in high producing dairy cows in Belgium: A field study. Therio. 2000: 53; 841-857.

[45] Butler W. Energy balance relationships with follicular development, ovulation and fertility in postpartum dairy cows. Livest Prod Sci. 2003: 83; 211-218.

[46] Tibary A, Anouassi A. Ultrasonographic changes of the reproductive tract in the female camel (Camelus Dromedarius) during the follicular cycle and pregnancy. J Camel Pract Res. 1996: 3; 71-90.

[47] Herenda D. Abattoir survey of reproductive organ abnormalities in beef heifers. Canada Vet J. 1987: $28 ; 33-36$.

[48 Hegazy AA, Ali A, Al-Aknah M, Ismail S. Studies on pituitary- ovarian axis in the female camel with special reference to cystic and inactive ovaries. J Cam Sci. 2004: 16-24.

[49] Vanholder T, Opsomer G, Kruif A. Aetiology and pathogenesis of cystic ovarian follicles in dairy cattle: a review. Repr and Nutr Dev. 2006:105-119.

[50] Roberts SJ. Veterinary Obstetrics and Genital Diseases. $3^{\text {rd }}$ edit., Roberts SJ -Woodstock, NewYork.1986: 381359.

[51] Alam M G S. Abattoir studies of genital diseases in cows. J Vet Rec. 1984: 195-196.

[52] Peter AT, Levine H, Drost M, Bergfelt DR. Compilation of classical and contemporary terminology used to describe morphological aspects of ovarian dynamics in cattle. Therio. 2009: 1343-1357.

[53] Monaco D, Padalino B, Lacalandra GM. Distinctive features of female reproductive physiology and artificial insemination in the dromedary camel species. Emi J Food and Agri. 2015: 328-337.

[54] Fathalla M, Hailat N, Lafi SQ. An abattoir survey of gross reproductive abnormalities in the bovine genital tract in Northern Jordan. Israel J Vet Med. 2000: 1-7.

[55] Tibary A, Anouassi A. Reproductive disorders of the female camelidae. In: Tibary A (ed) Theriogenology in camelidae: anatomy, physiology, BSE, pathology and artificial breeding: actes editions. Reports of Agronomy and Veterinary Institute Hassan; 1997: 317-368.

[56] Fetaih H. Some pathological studies on the affections of genital system of she-camel. PhD Thesis, Faculty of veterinary medicine, Suez Canal University. 1991

[57] Tibary A, Anouassi A. Reproductive disorders in the female camelid. In: Recent advances in camelid reproduction, Skidmore JA, Adams GP Eds., International Veterinary Information Service. 2000: http://www.ivis.org/, access 22/6/2014. 
[58] Jubb KVF, Kennedy PC, Palmer N. Pathology of domestic animals. In: $4^{\text {th }}$ San Diego, Eds., Academic press: California, London.1993

[59] El-Yuguda AD, Abubakar MB, Baba SS, Ngangnou A. Competitive ELISA rinderpest virus antibody in slaughtered camels (Camelus dromedarius): implication for rinderpest virus elimination from Nigeria. Afr J Biom Res. 2010:8385.

[60] Tadesse, Y., Urge M., Abegaz S., Kurtu Y.M., and Kebede K. Camel and cattle population dynamics and livelihood diversification as a response to climate change in pastoral areas of Ethiopia. 2013: 25; 166. Livestock research for rural development.

[61] Tefera, M., Abebe, G., (eds). Camel in Ethiopia. Ethiopian Veterinary Association. 2012: 188.

[62] Tibary A. "Infertility in female Camelids." Reproductive patterns and examination technique. Large Animal Proceedings of the North American Veterinary Conference, January $17^{\text {th }}-21^{\text {st }}, 2004: 18: 285-286$.

[63] Foldi J, Kulcsar M, Pecsi A, Huyghe B, DeSa C et al. Bacterial complications of postpartum uterine involution in cattle. Ani Repro Sci. 2006: 96; 265-281.

[64] Lacey, M. and Rosenberg, F. Cystic Ovaries in Dairy Cattle California Polytechnic State University, San Luis Obispo. 2010:1-6

[65] Tsianos, G.P., Stefania, M. M., George K. and Theodor S. Pyosalpinx a Case Report. J Vet Med. 2011: 5: 546-546

[66] Powers, B.E., Johnson, L.W., Linton, L.B., Garry, F. and Smith, J. Endometrial biopsy technique and uterine pathologic findings in Ilamas. J Am Vet Med Assoc. 1990: 197; 1157-1162.

\section{Figures}



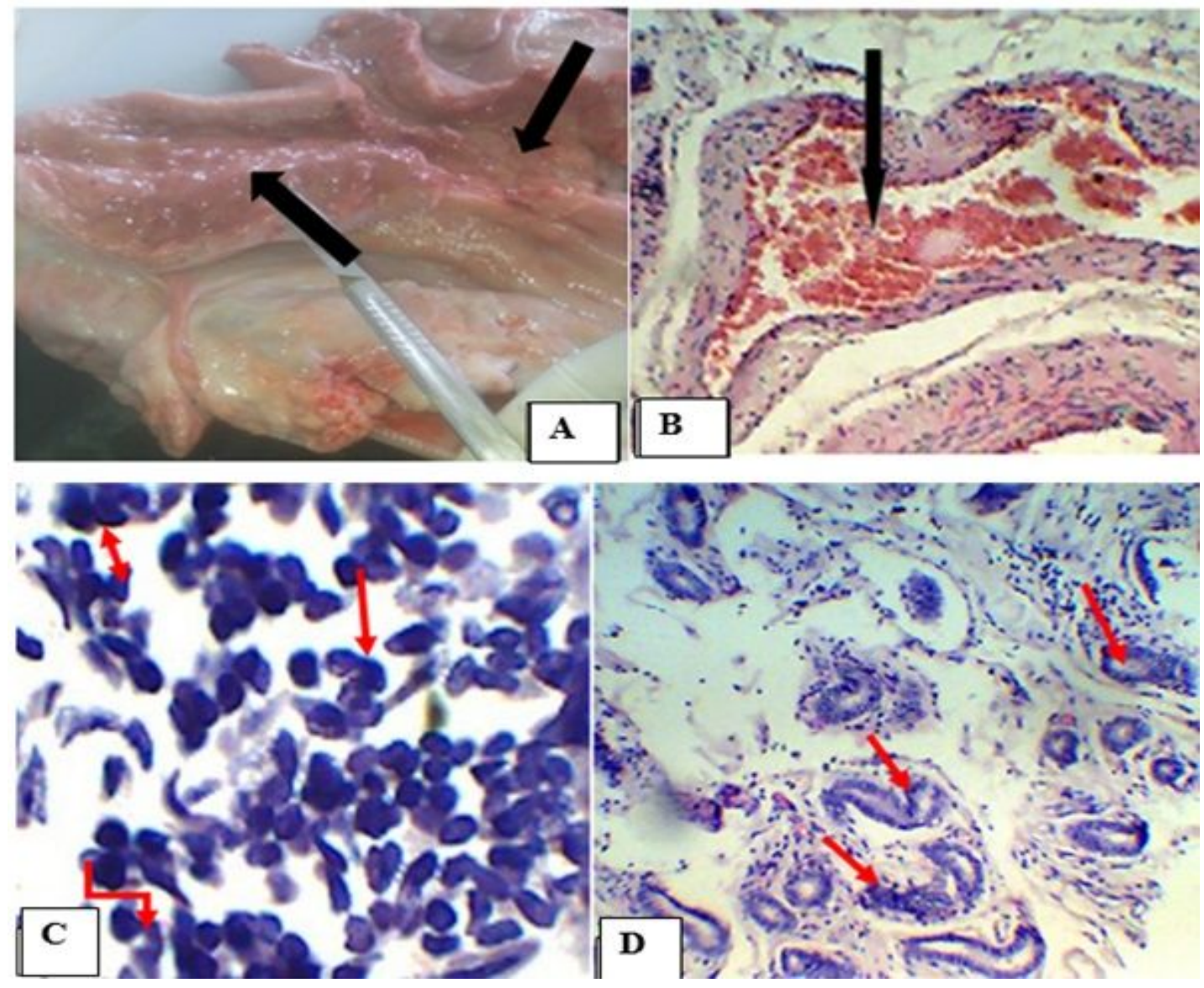

Figure 1

Endometritis in camels. A. Severely hyperemic acute endometritis with blood tinged exudates in the upper corner; B. Congestion of endometrial blood vessels; C. Aggregation of neutrophyls. Hematoxylin-Eosin stain 100X; D. Misshapen and atrophied endometrial gland. Hematoxylin-Eosin stain 40X.

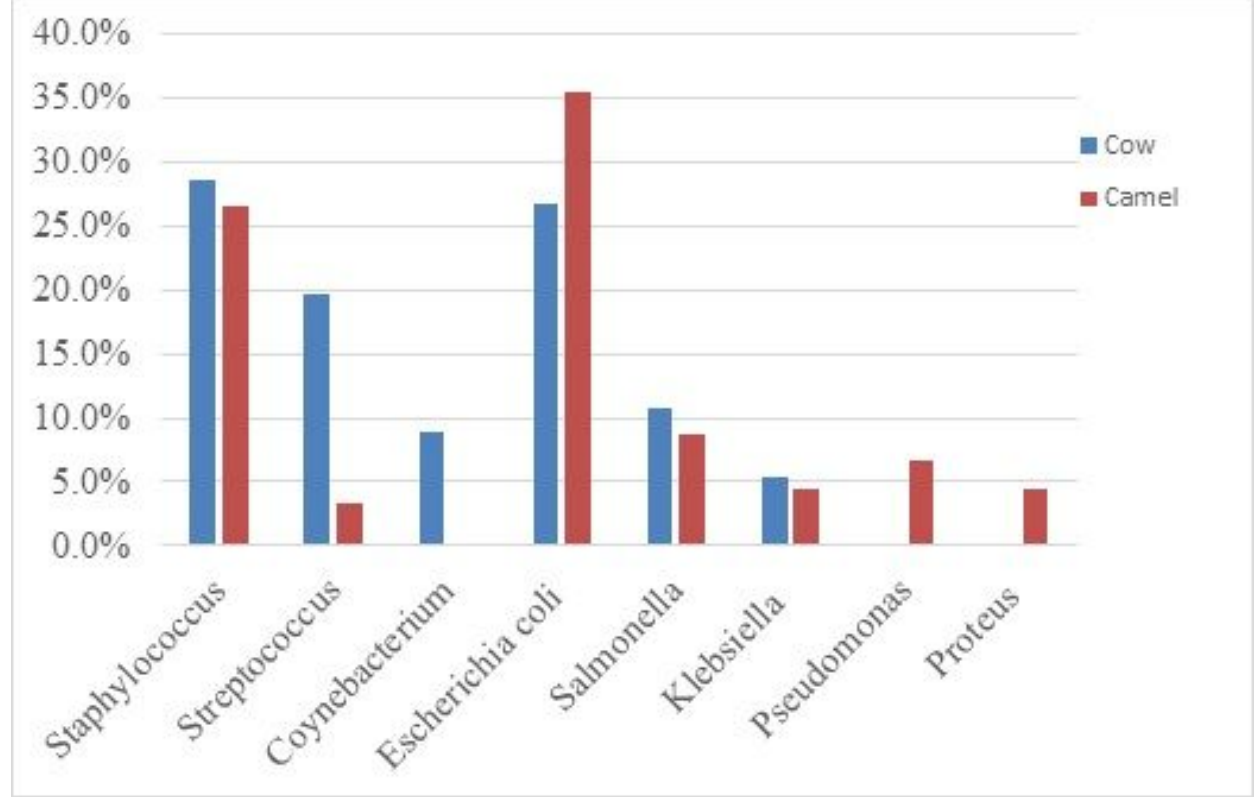

Figure 1

Graphical presentation of bacteria isolated from uterine lesions. 

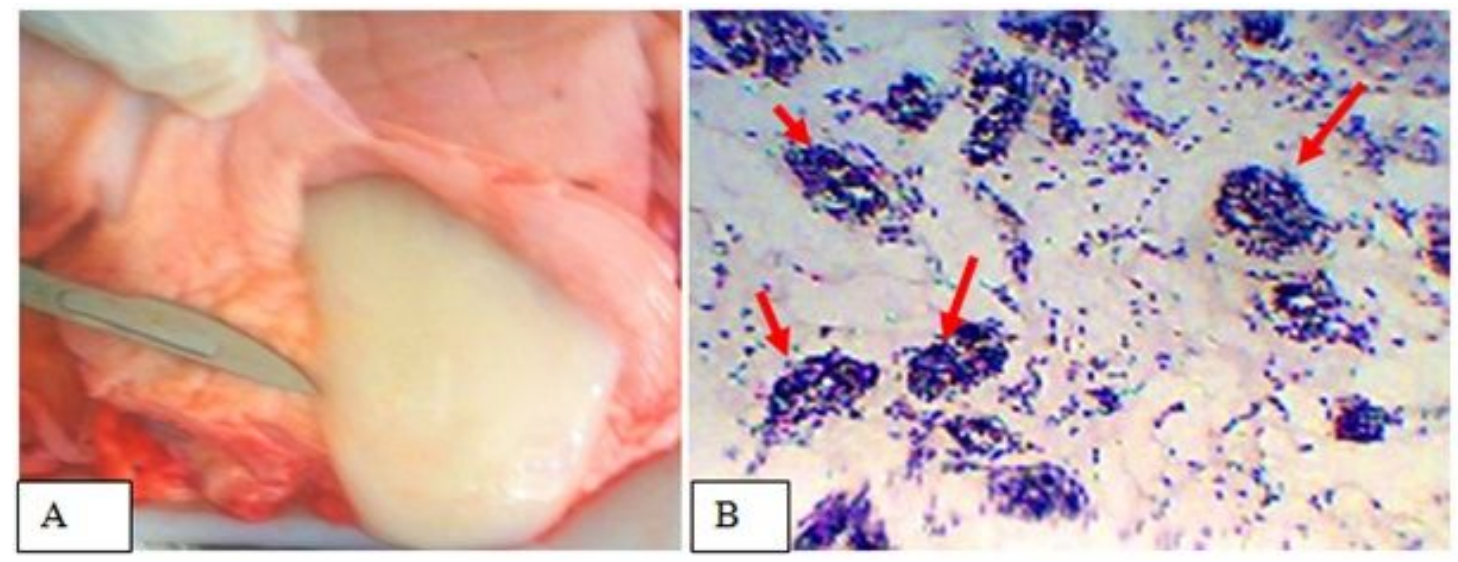

\section{Figure 1}

Catarrhal endometritis in a cow. A. Note the catarrhal exudates discharged from vagina; B. Microscopic endometrial gland degeneration. Hematoxylin-Eosin stain 40X

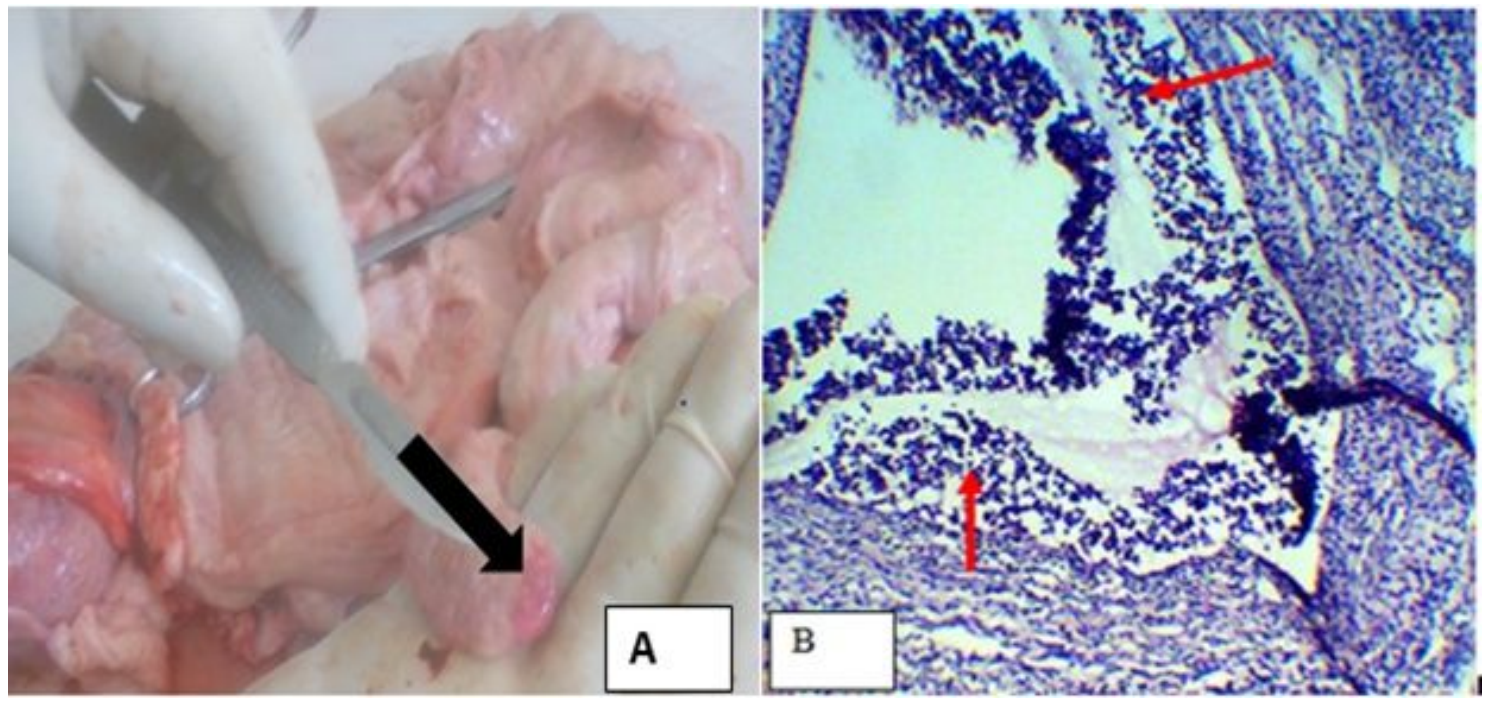

Figure 1

Oophoritis in a camel female. A. Note hyperemic and swollen ovary; B. Inflammatory cells infiltrations in ovarian medullary region. Hematoxylin-Eosin stain X 40 . 

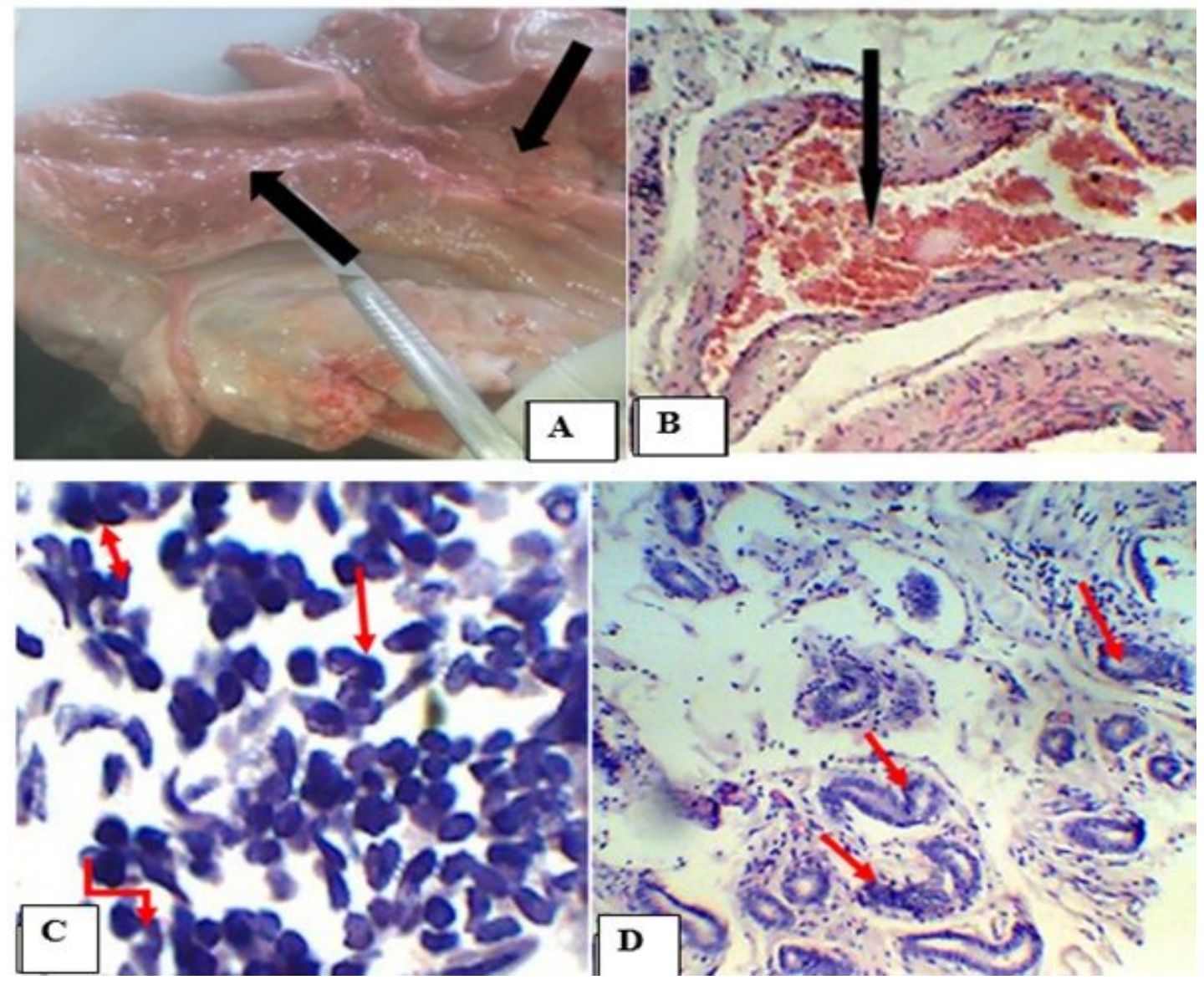

Figure 1

Endometritis in camels. A. Severely hyperemic acute endometritis with blood tinged exudates in the upper corner; B. Congestion of endometrial blood vessels; C. Aggregation of neutrophyls. Hematoxylin-Eosin stain 100X; D. Misshapen and atrophied endometrial gland. Hematoxylin-Eosin stain 40X.

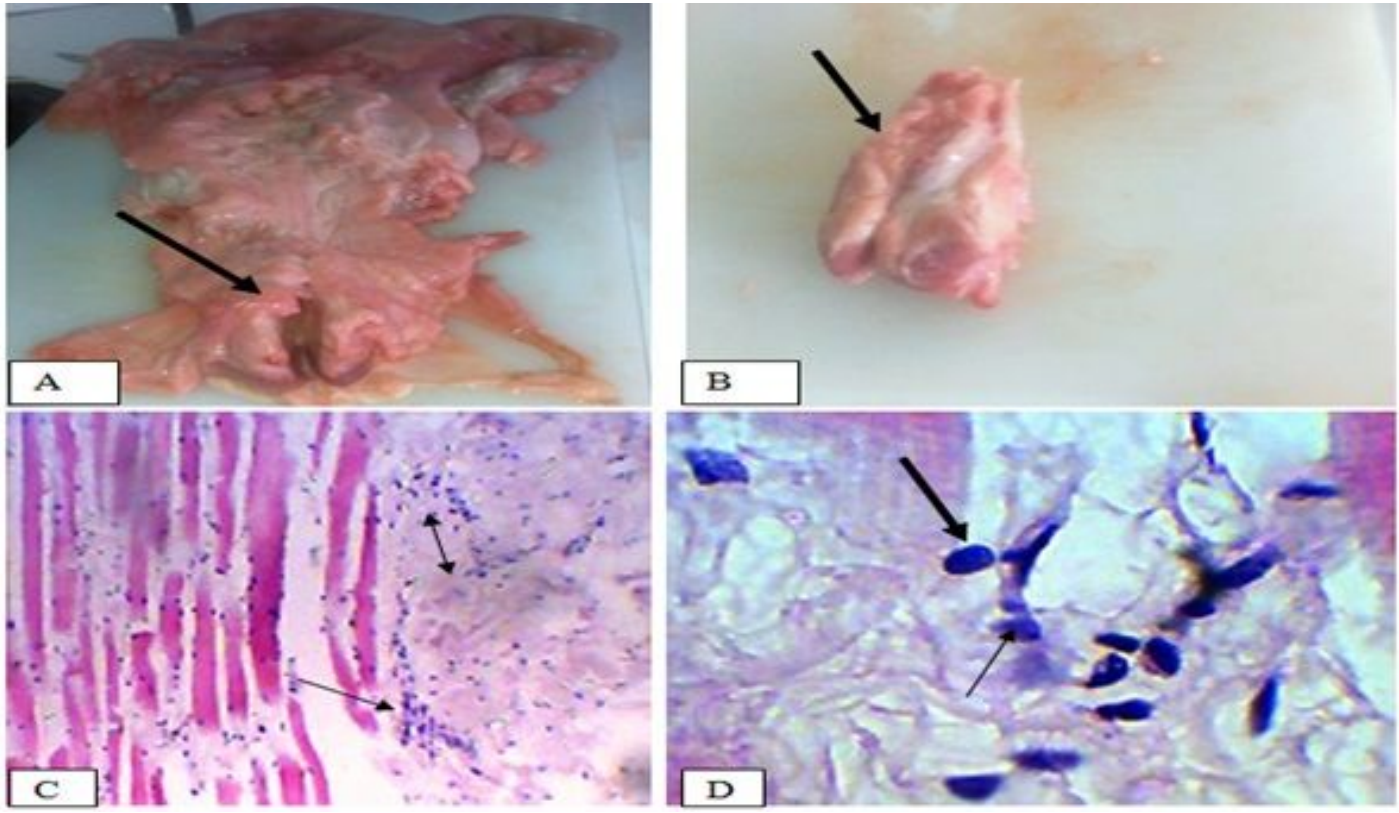

Figure 1 
Vaginal myositis in a camel female. A. Cross section of swelling mass in the wall of the vagina; B. Tumor like mass after removed from the wall; C. Sloughed myocytes Hematoxylin-Eosin stain X40; D. lymphocytes infiltration between myocytes. Hematoxylin-Eosin stain X 100

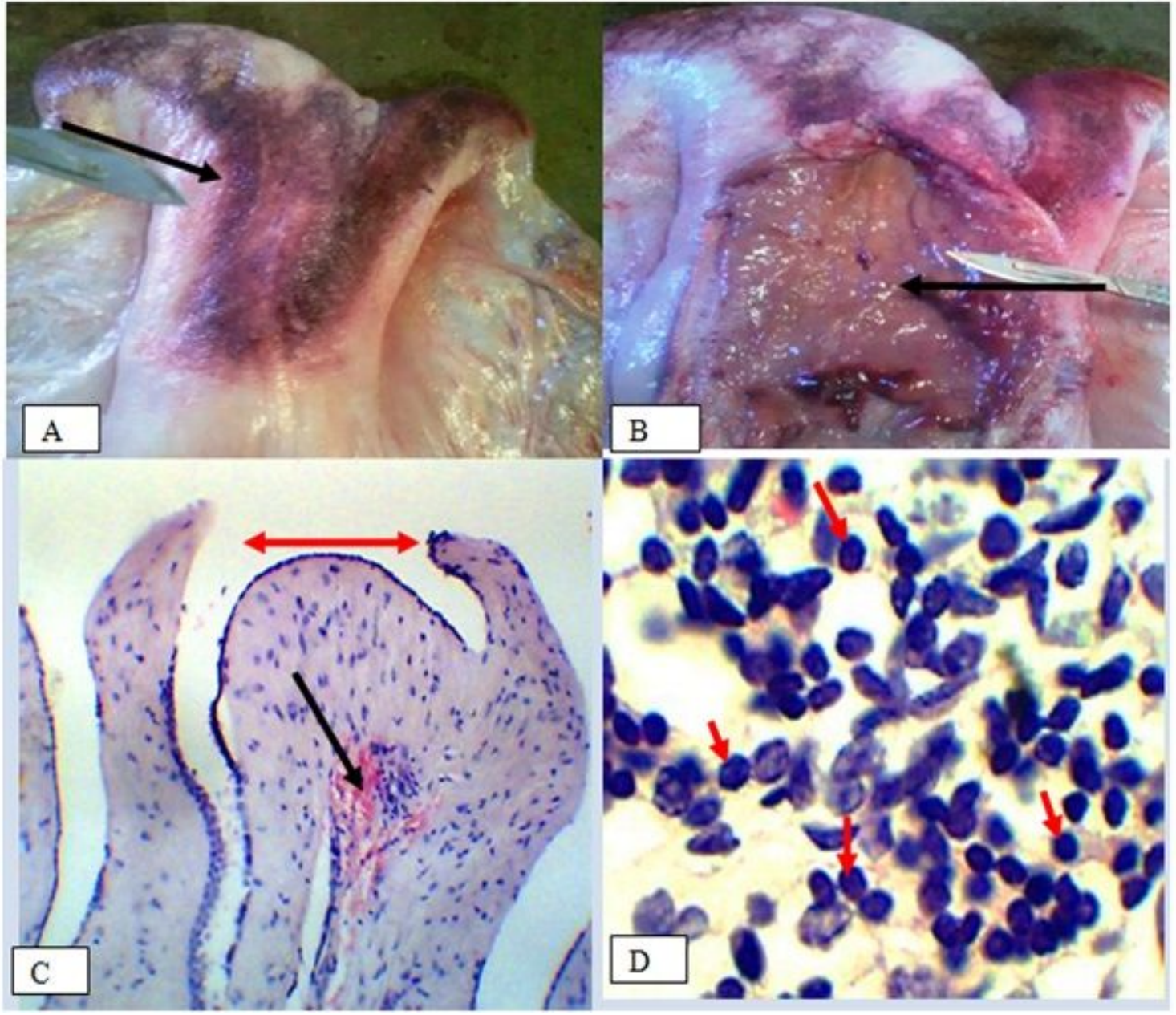

Figure 1

Chronic endometritis in a camelid female. A. Note severe congestion visible from outside; B. Severely congested and thickened mucosa on incision; C. Severely hyperplastic mesetholium (red two-sided arrow) and hemorrhage (black arrow) Hematoxylin-Eosin stain 40x; D. Lymphocytes infiltrations in endometrium. Hematoxylin-Eosin stain100x
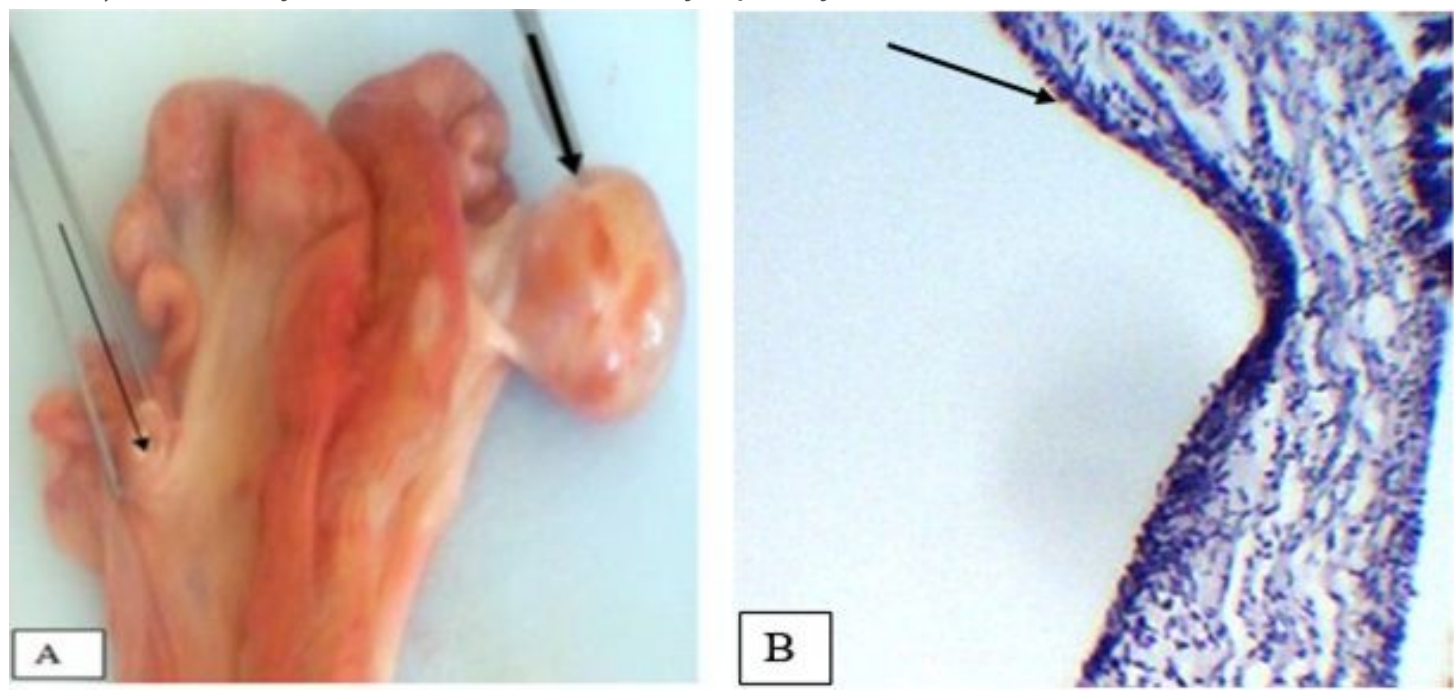
Figure 1

Follicular cysts in a cow. A. On gross inspection, it can be noticed that the cyst occupies the entire right ovary and very thin wall due to distention by follicular fluid indicated (short thick arrow); the contralateral ovary is inactive (arrow); B. Microscopic evaluation showed the cyst walls composed of extremely thin granulosa cells (black arrow). Hematoxylin-Eosin stain X 40.

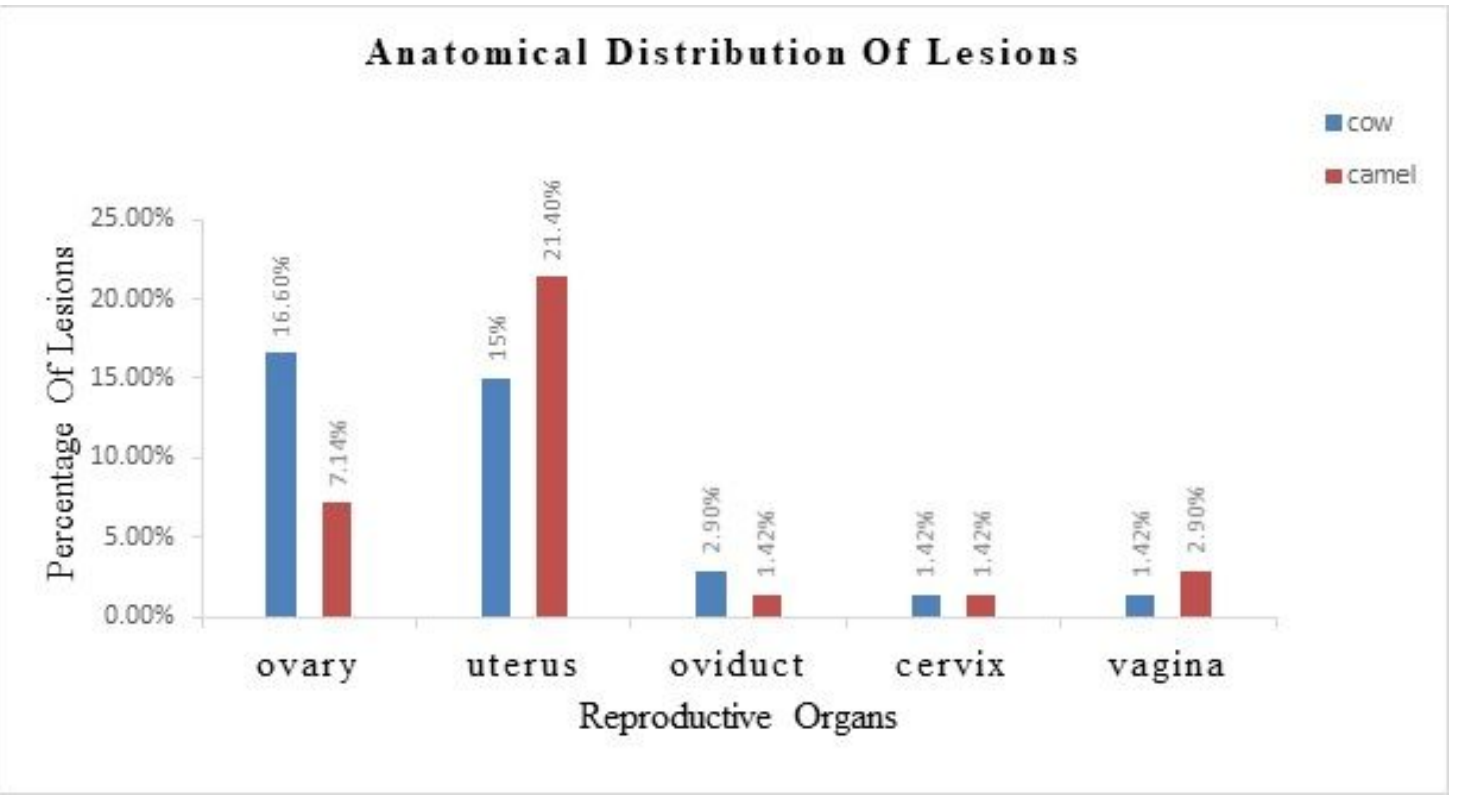

Figure 1

Anatomical distribution of reproductive organ lesions in cow and dromedary camel

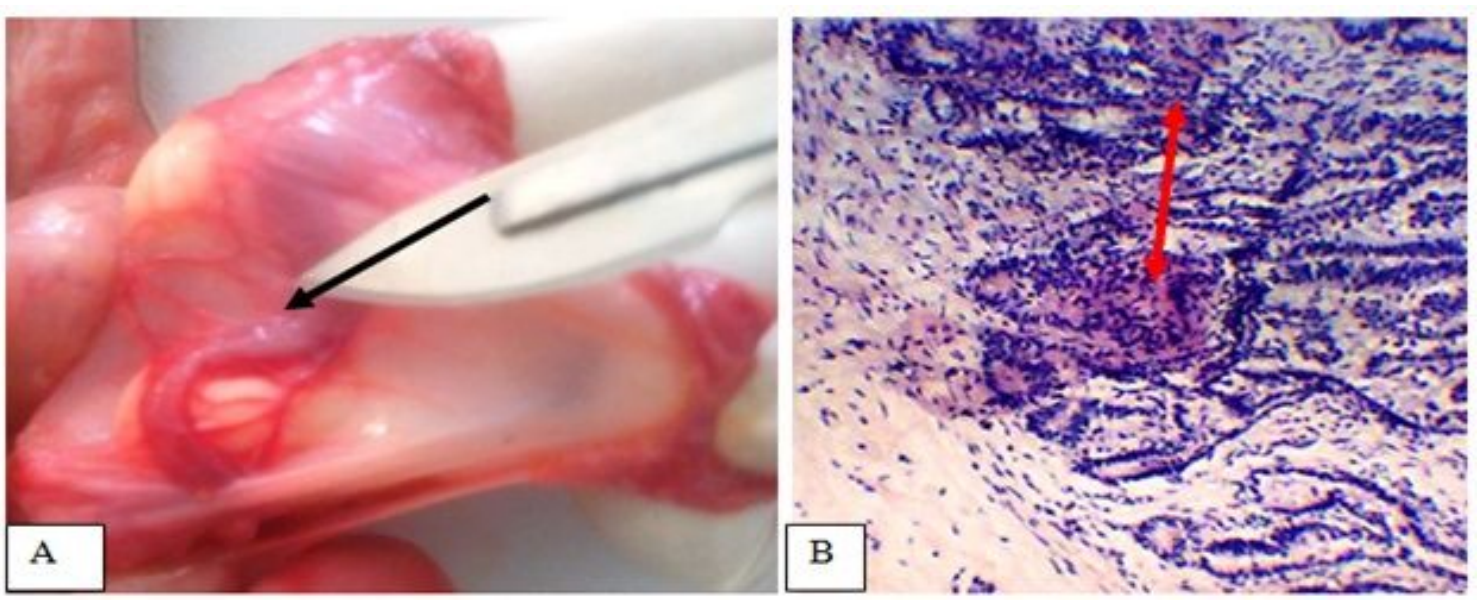

Figure 1

Hemosalphinx in a cow. A. Note the mucosa was hyperemic and the lumen filled with bloods; B. Microscopically edema and inflammatory cell infiltrations (red arrow). Hematoxylin-Eosin stain X 40 


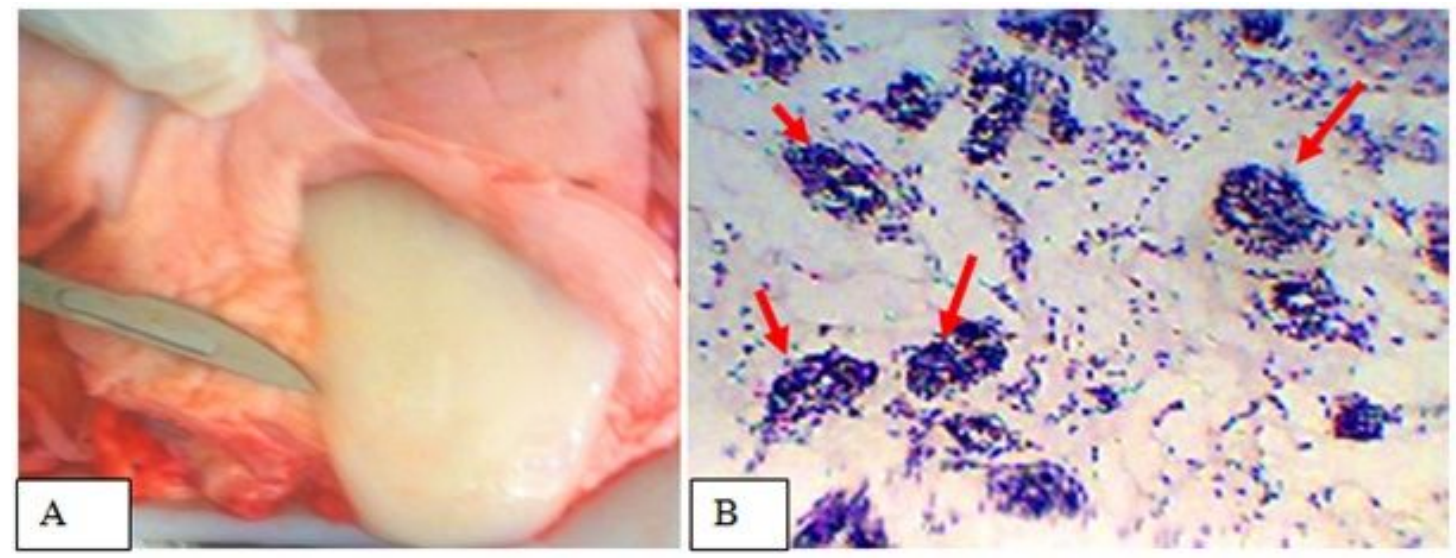

Figure 1

Catarrhal endometritis in a cow. A. Note the catarrhal exudates discharged from vagina; B. Microscopic endometrial gland degeneration. Hematoxylin-Eosin stain 40X

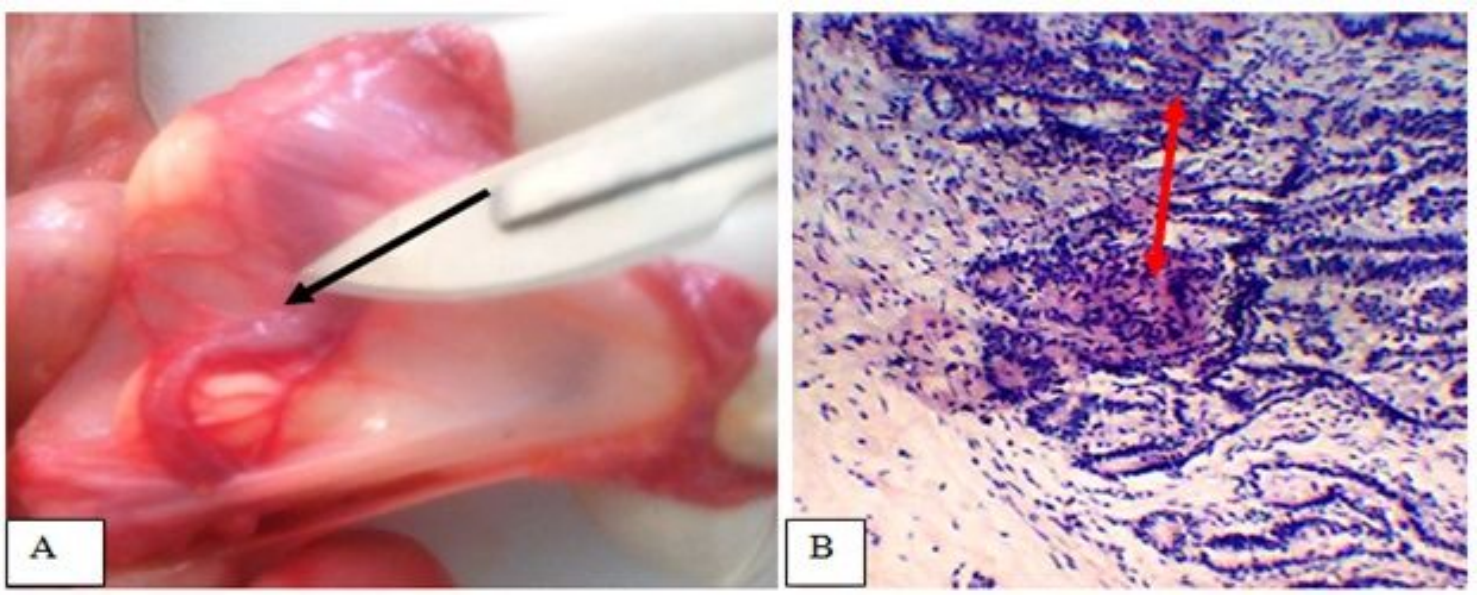

Figure 1

Hemosalphinx in a cow. A. Note the mucosa was hyperemic and the lumen filled with bloods; B. Microscopically edema and inflammatory cell infiltrations (red arrow). Hematoxylin-Eosin stain X 40

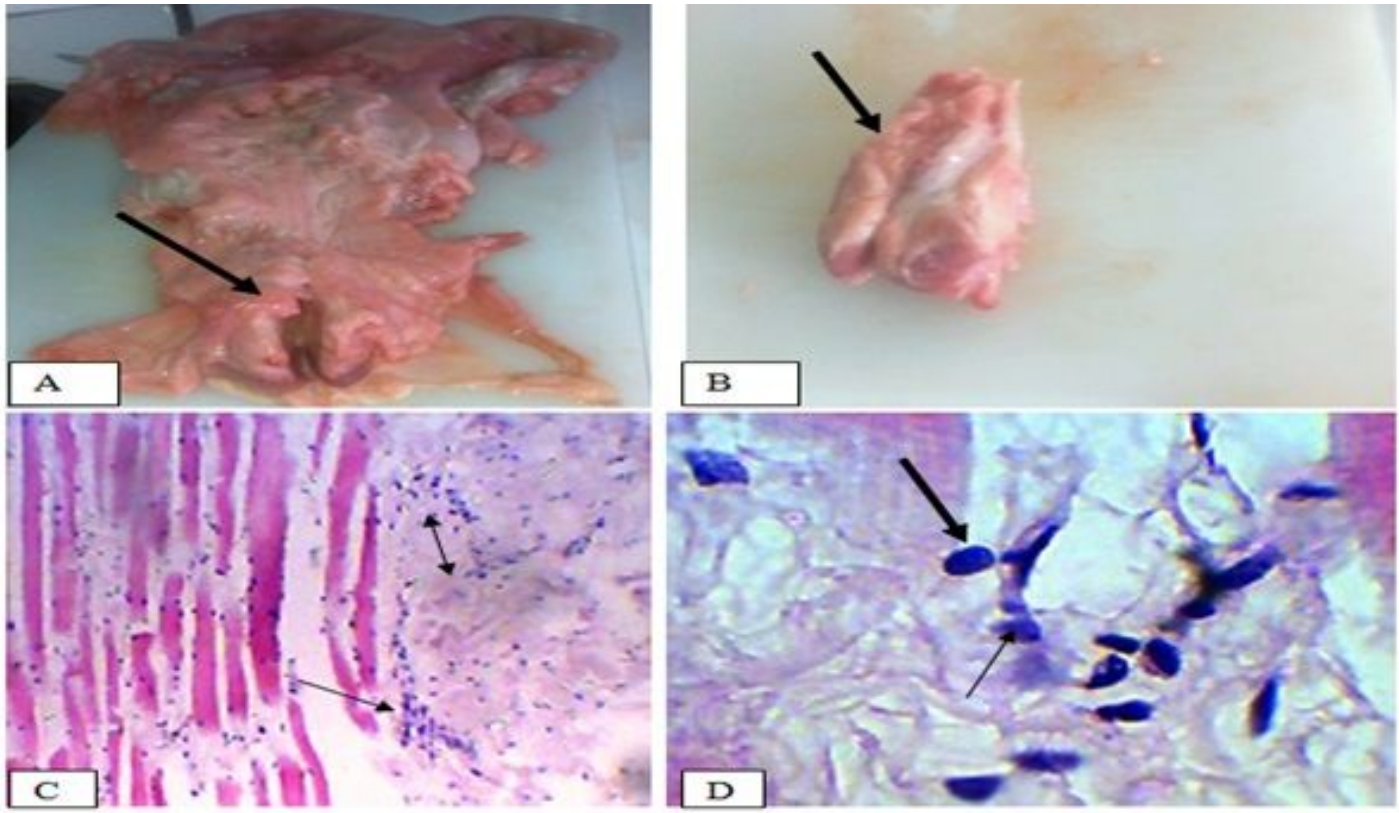




\section{Figure 1}

Vaginal myositis in a camel female. A. Cross section of swelling mass in the wall of the vagina; B. Tumor like mass after removed from the wall; C. Sloughed myocytes Hematoxylin-Eosin stain X40; D. lymphocytes infiltration between myocytes. Hematoxylin-Eosin stain X 100
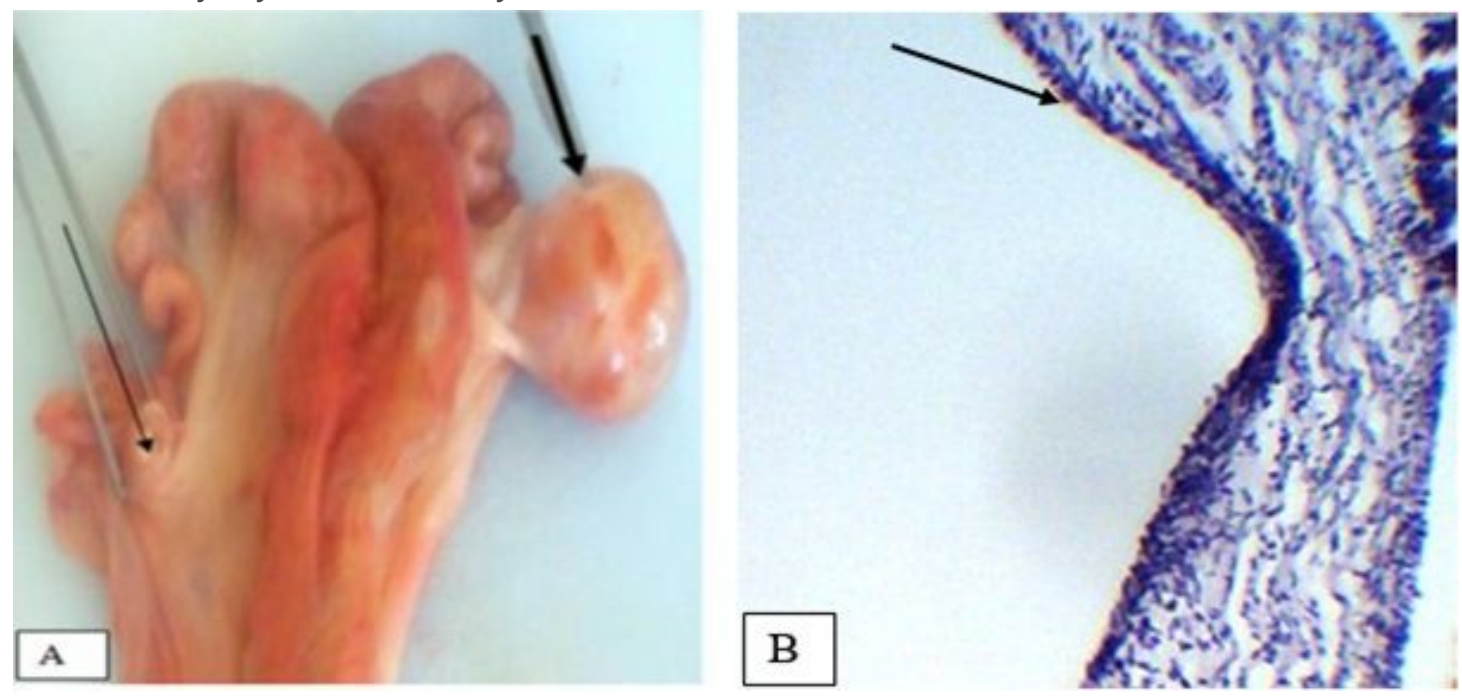

Figure 1

Follicular cysts in a cow. A. On gross inspection, it can be noticed that the cyst occupies the entire right ovary and very thin wall due to distention by follicular fluid indicated (short thick arrow); the contralateral ovary is inactive (arrow); B. Microscopic evaluation showed the cyst walls composed of extremely thin granulosa cells (black arrow). Hematoxylin-Eosin stain X 40 .

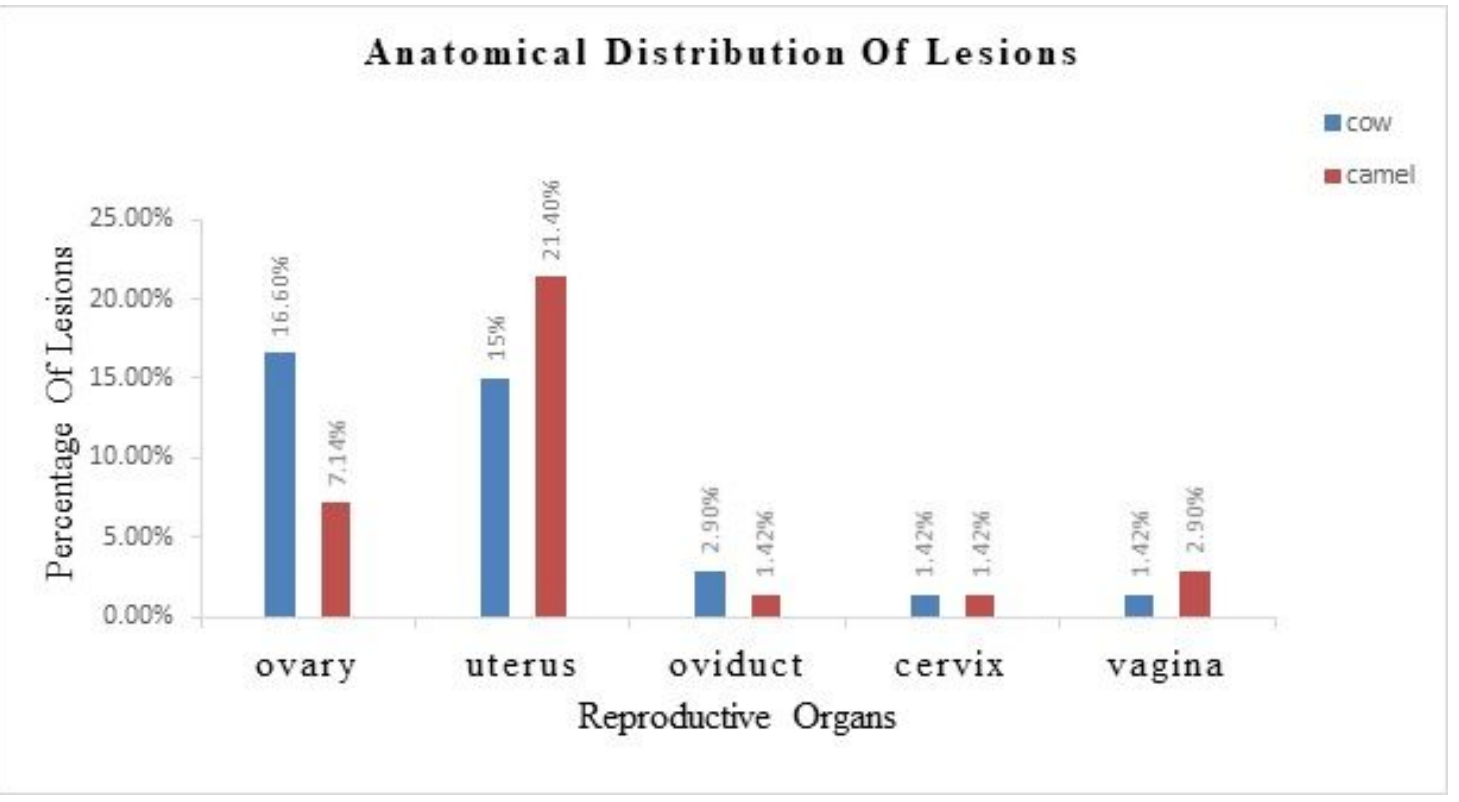

\section{Figure 1}

Anatomical distribution of reproductive organ lesions in cow and dromedary camel 

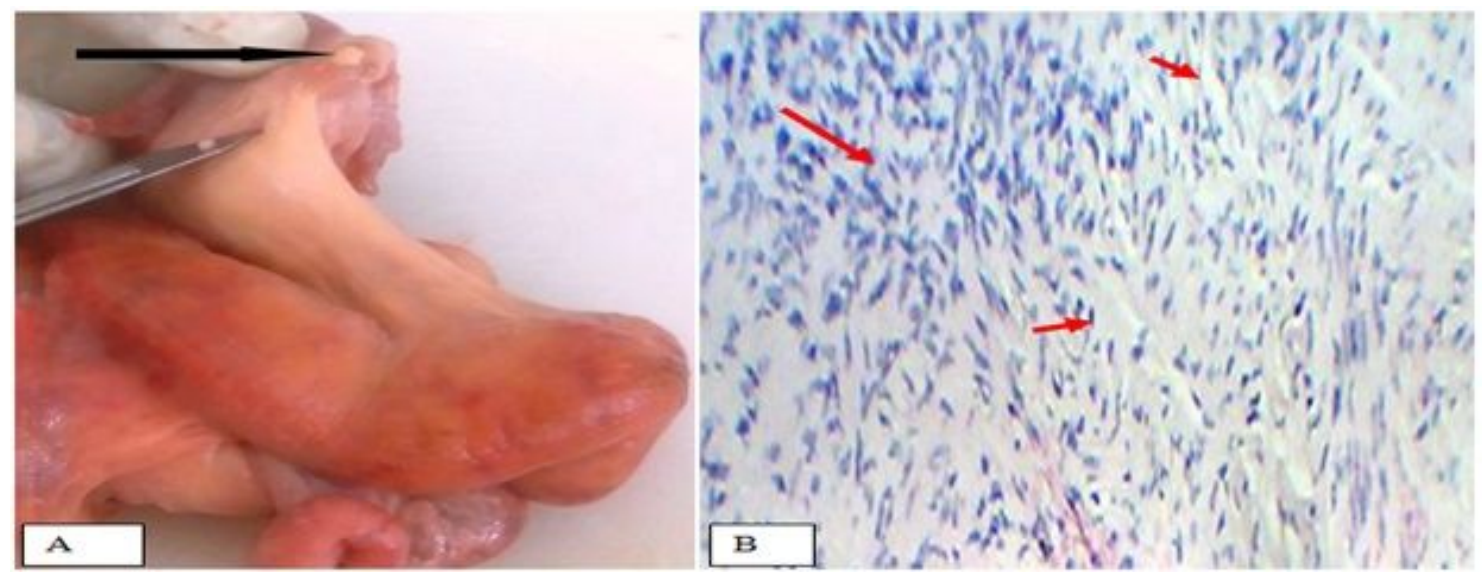

\section{Figure 1}

In active cow ovary. A. Note the small size ovary. B. Excessive fibrous connective tissues proliferation with complete absence of follicular or luteal development. Hematoxylin-Eosin stain X 40

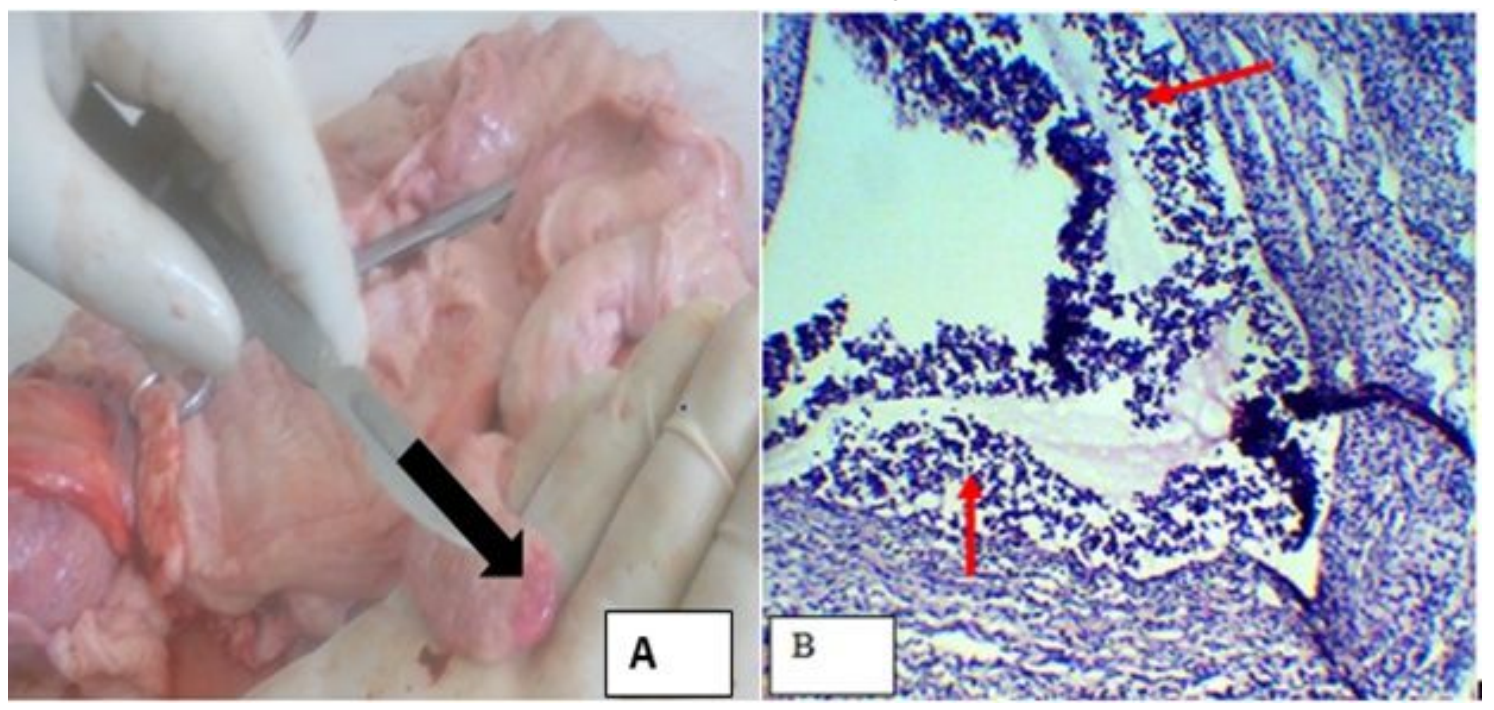

Figure 1

Oophoritis in a camel female. A. Note hyperemic and swollen ovary; B. Inflammatory cells infiltrations in ovarian medullary region. Hematoxylin-Eosin stain X 40.
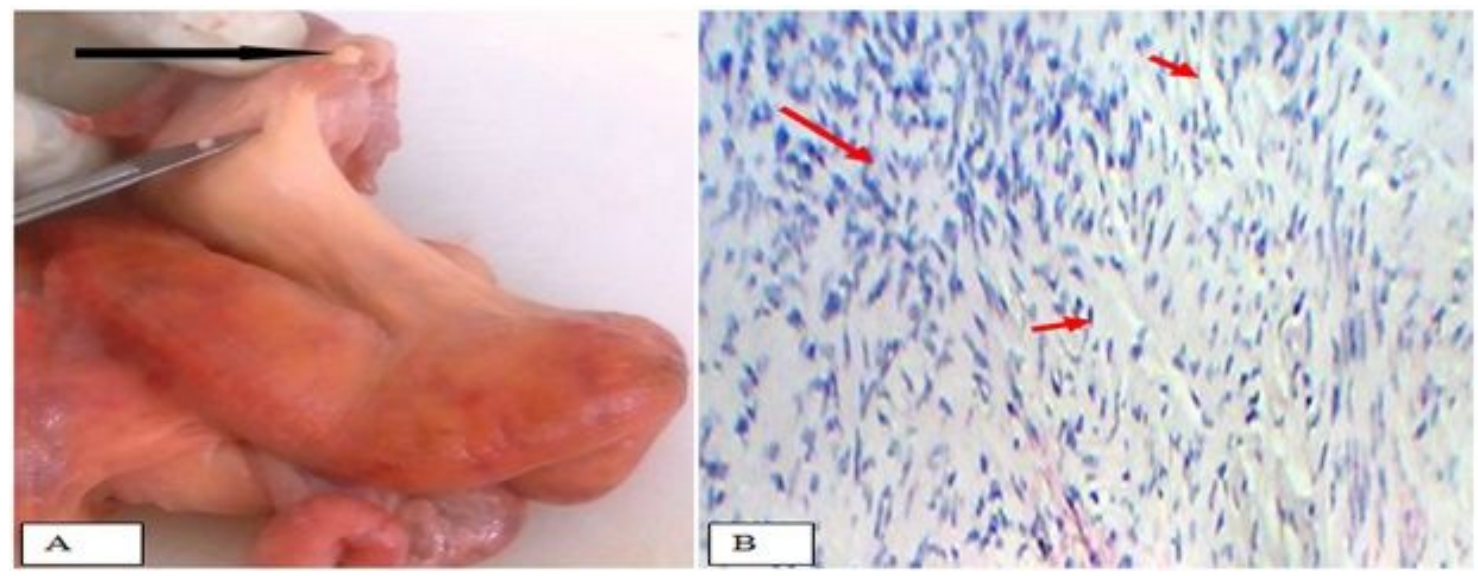

Figure 1 
In active cow ovary. A. Note the small size ovary. B. Excessive fibrous connective tissues proliferation with complete absence of follicular or luteal development. Hematoxylin-Eosin stain X 40
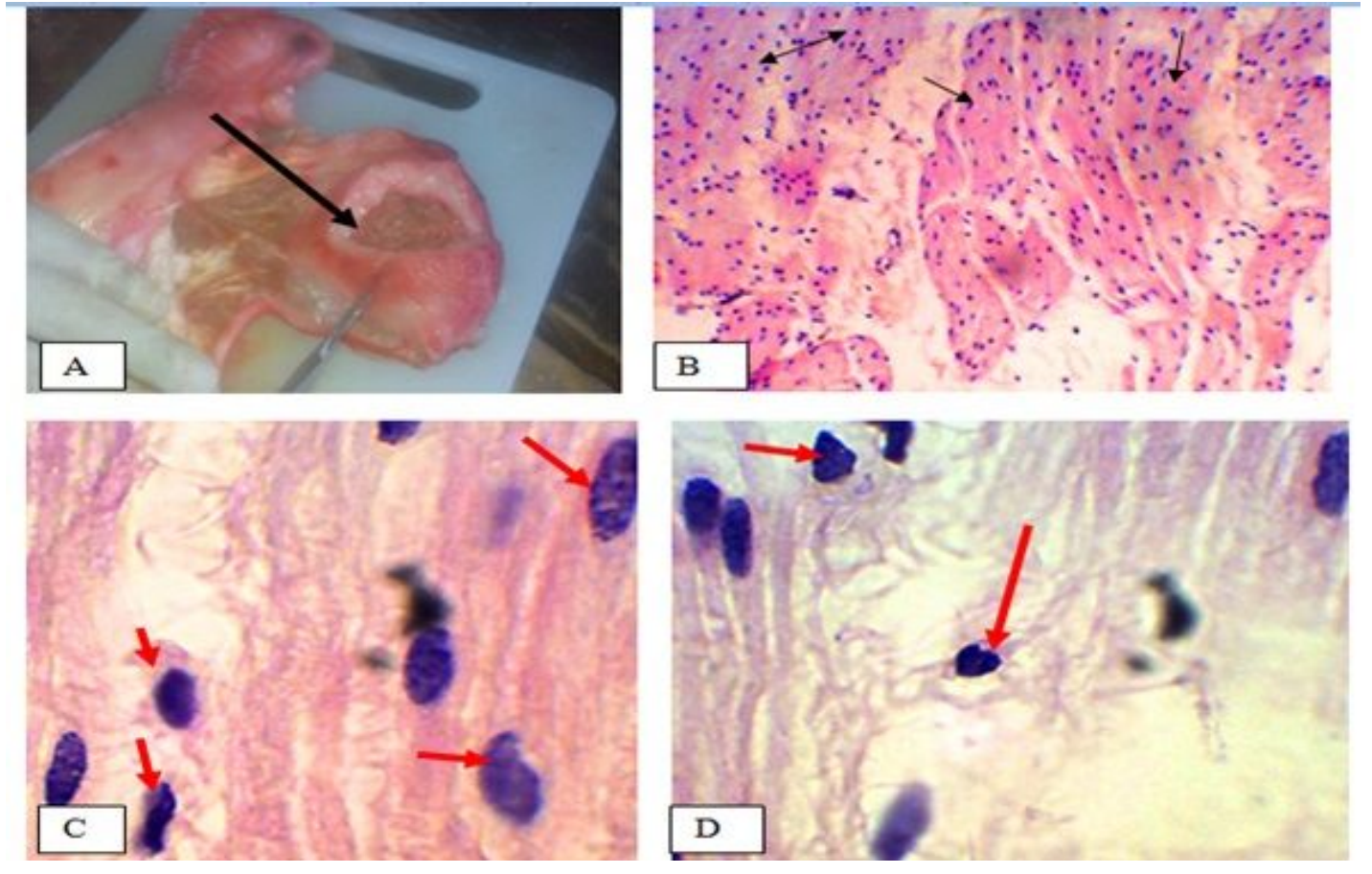

\section{Figure 1}

Leiomyoma in a cow. A. Firmly attached mass originated from body of uterus; B. Bundles of smooth muscles running in various directions and interlaced with each other are observed. Hematoxylin-Eosin stain X 40; C. variation of nucleus shape; D. slight mitotic figure (red arrow). Hematoxylin-Eosin stain X100. 


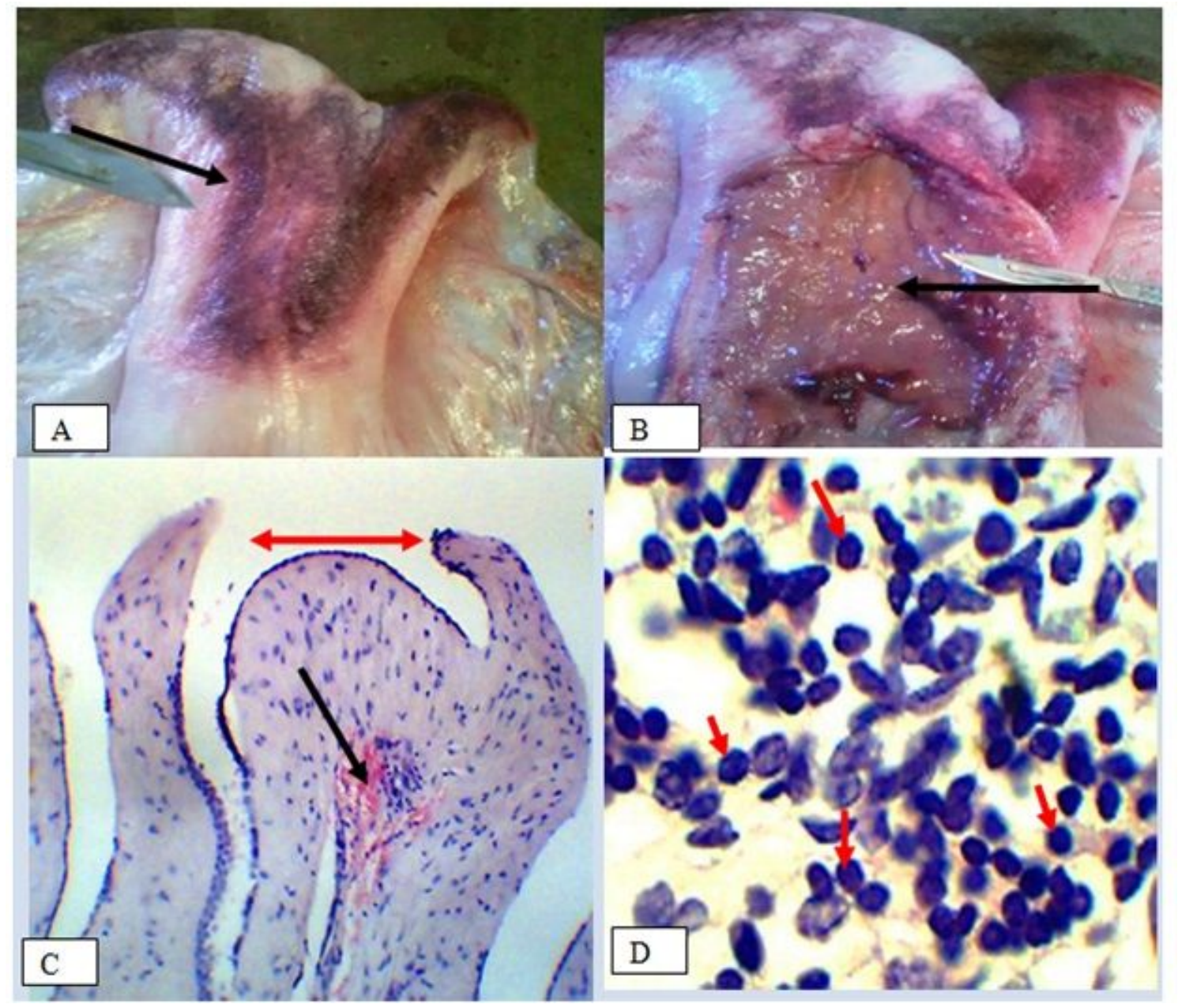

Figure 1

Chronic endometritis in a camelid female. A. Note severe congestion visible from outside; B. Severely congested and thickened mucosa on incision; C. Severely hyperplastic mesetholium (red two-sided arrow) and hemorrhage (black arrow) Hematoxylin-Eosin stain 40x; D. Lymphocytes infiltrations in endometrium. Hematoxylin-Eosin stain100x

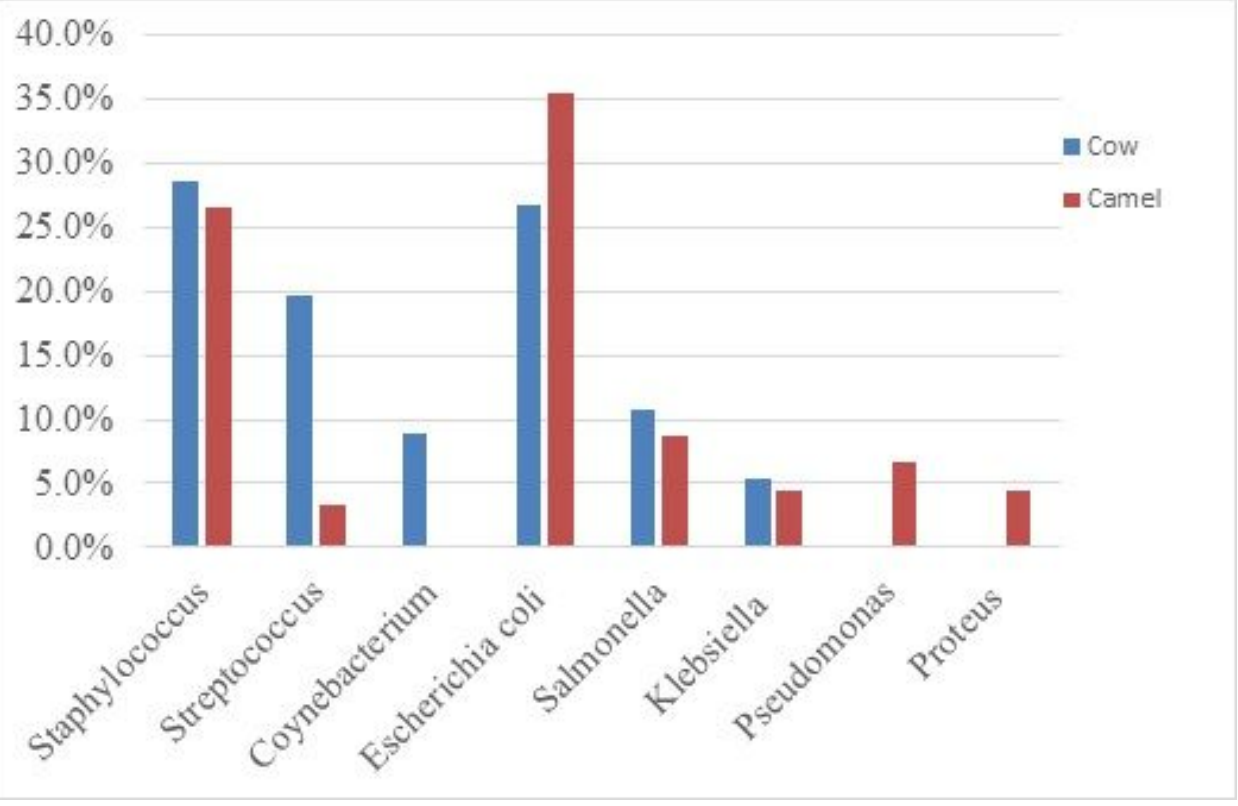

Figure 1 
Graphical presentation of bacteria isolated from uterine lesions.
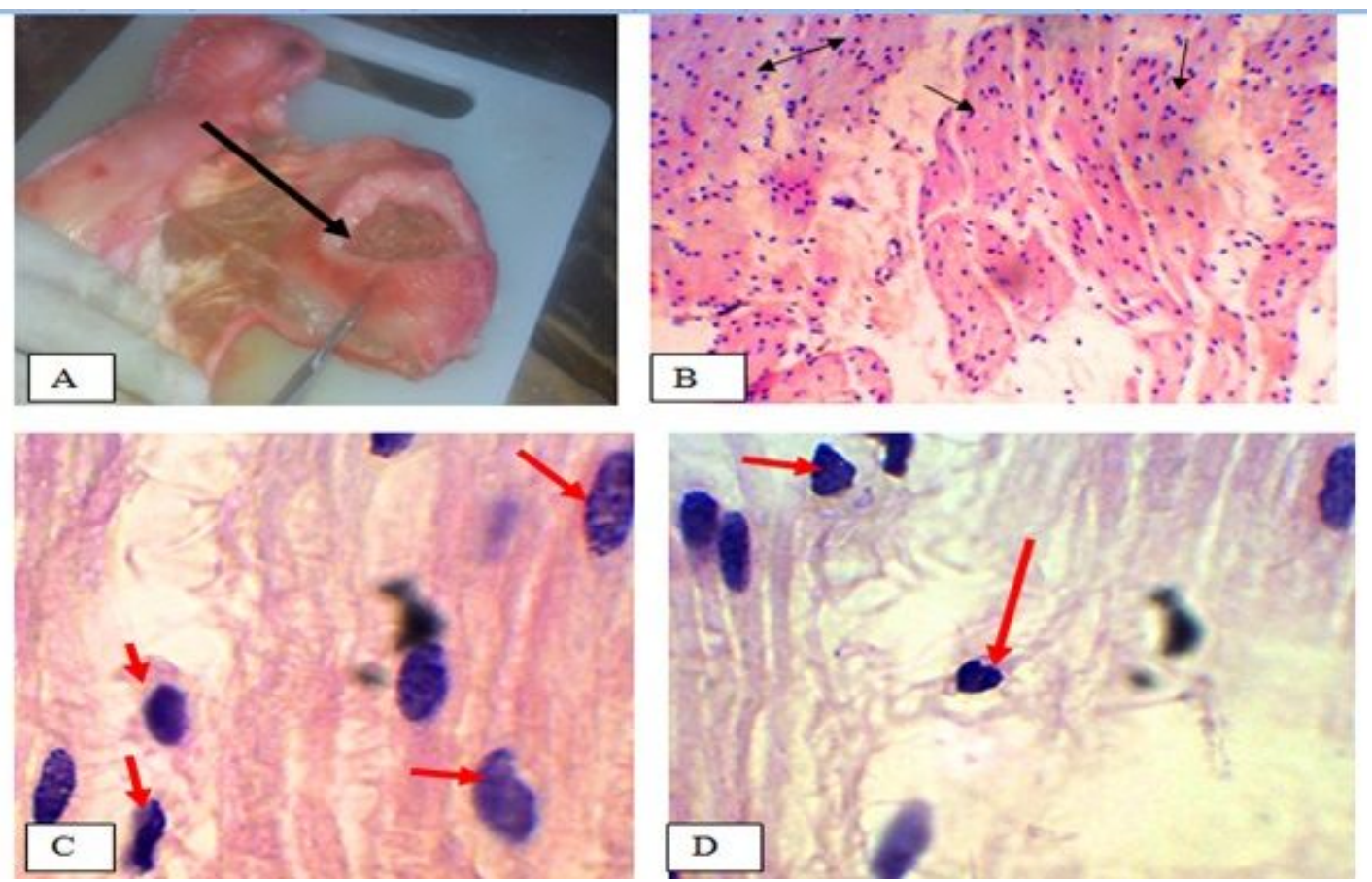

\section{Figure 9}

Leiomyoma in a cow. A. Firmly attached mass originated from body of uterus; B. Bundles of smooth muscles running in various directions and interlaced with each other are observed. Hematoxylin-Eosin stain X 40; C. variation of nucleus shape; D. slight mitotic figure (red arrow). Hematoxylin-Eosin stain X100.

\section{Supplementary Files}

This is a list of supplementary files associated with this preprint. Click to download.

- Revisedlesionscharacterization.pdf

- Revisedlesionscharacterization.pdf 